\title{
21. Results at any Cost? The Legacy of 2002 in Koroba-Lake Kopiago Open Electorate
}

\author{
Nicole Haley
}

In June 2007, the people of Koroba-Lake Kopiago went to the polls for the fourth time in five years. The election was of particular interest because Koroba-Lake Kopiago was one of the six open electorates in which the 2002 general election had been deemed to have failed, and was one of the 10 electorates around the country that had had a limited preferential voting (LPV) by-election prior to the general election. It is also an electorate that has been subject to election studies in the past (see Haley 2002, 2004, 2006 and Robinson 2002) and for which there is consequently a great deal of comparative longitudinal data. This chapter draws upon observations and findings of both the 2006 Koroba-Lake Kopiago by-election observation team (Haley 2006) and the 2007 Koroba-Lake Kopiago domestic observation team. ${ }^{1}$ It finds that the election was anything but fair, yet despite fraud and malpractice on a scale never before seen the election was widely held to have been successful and a significant improvement on 2002. It further suggests that the national government and Papua New Guinea Electoral Commission (PNGEC) were willing to accept results at any cost in order to avoid a repetition of the events of 2002 (Somare 2006:5), and advocates a more honest assessment of future elections. The integrity of elections cannot merely be asserted but must be demonstrated.

\section{Background}

Koroba-Lake Kopiago is one of eight open electorates in Southern Highlands Province (Figure 20.1). It is a large ethnically divided electorate situated in the far north-western corner of the province, sharing boundaries with Enga, Sandaun, East Sepik and Western provinces (Figure 21.1). The district comprises four local-level governments (LLGs) for census purposes-North Koroba LLG

\footnotetext{
1 The by-election observation team included Richard Alo, Kenny Kendoli, Philip Moya, Ben Randa and Susan Ferguson, while the 2007 domestic observation team included Anna Alo, Susan Alo, Jenny Lundape, Kipu Piaro, Saki Alo, Rodney Aporia, Mex Bibila, Kenny Kendoli, Petrus Kilapa, David Lundape, Jim Siape, Justin Wandi and Eka Wek. Both teams were led by Nicole Haley. Given the prevailing security situation in the electorate in 2007 several of the team positions were split. The four local women, for instance, shared a position and made observations in their home areas where their personal security could be more likely guaranteed.
} 
(26 wards), South Koroba LLG (23 wards), Lake Kopiago LLG (19 wards) and Auwi-Pori LLG (27 wards) - and three and a half LLGs for electoral purposes. Like several other LLGs in Southern Highlands Province, Auwi-Pori LLG is split between two open electorates, namely Koroba-Lake Kopiago and Tari-Pori Open. ${ }^{2}$ This has proved to be an ongoing source of confusion to voters and electoral officials alike.

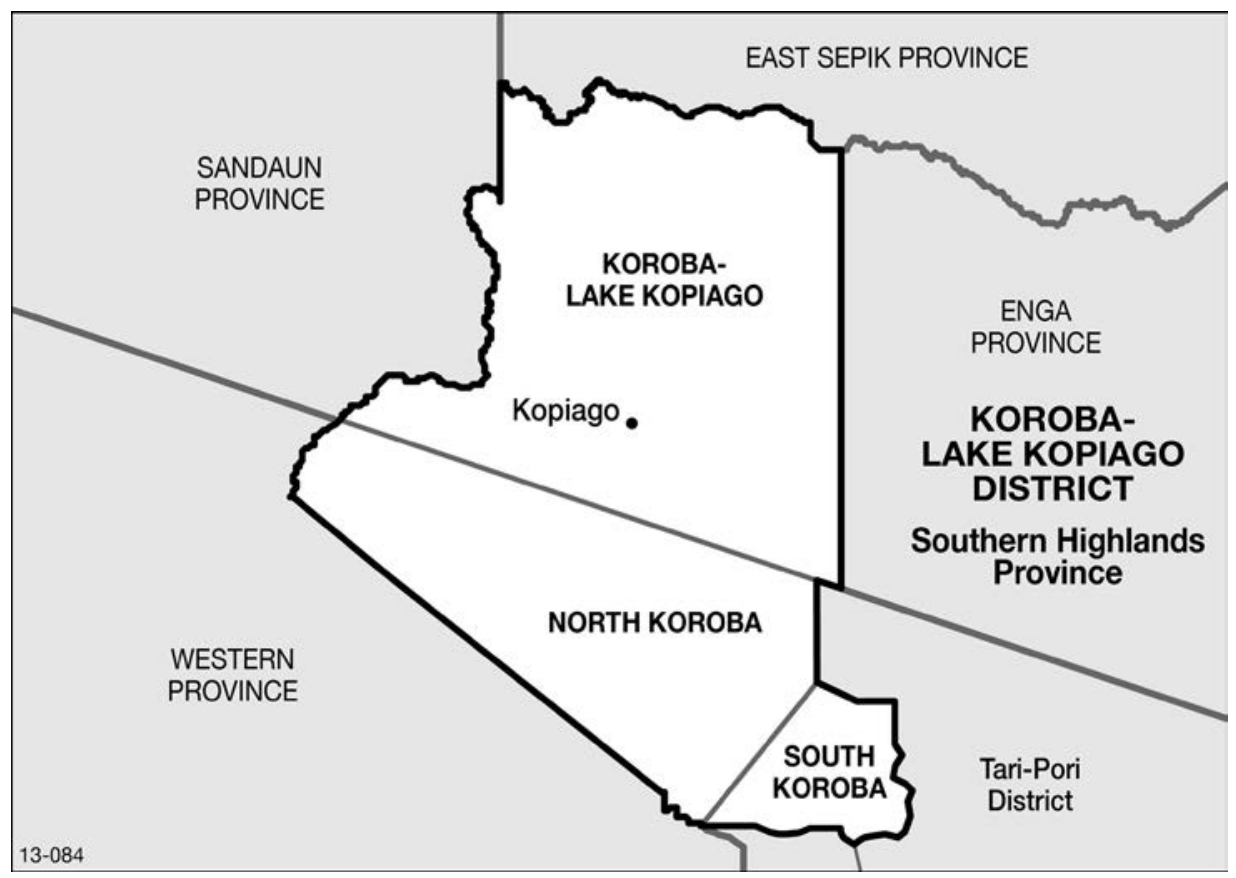

Figure 21.1: Koroba-Lake Kopiago District

Koroba-Lake Kopiago Open electorate extends northwest from Koroba and Mogorofugwa - two densely populated wetland basins inhabited by Huli speakers - towards the Strickland-Lagaip river junction, thereby taking in the country of the Duna, Hewa, Bogaia and Awi peoples. Much of the electorate (especially the northwest) is accessible only by air, or several days walking with hazardous river crossings. Political leaders (including many of the ward councillors) spend little, if any, time in the district and vast majority of public servants are also absent. As a consequence there is little by the way of government service delivery and armed conflict is commonplace, as are illegal weapons (see Haley and Muggah 2006).

2 Auwi-Pori LLG comprises 27 wards. Thirteen wards vote in Koroba-Lake Kopiago Open electorate and 14 wards in Tari-Pori Open electorate. The Auwi-Pori LLG headquarters are at Tugu, which is in the Pori sub-district. 
As at the 2007 election, the electorate was home to around 55,000 people, ${ }^{3}$ although there were in fact over 48,700 names on the new electoral roll. Of the electorate's residents approximately 33,500 (61 percent) primarily identify as Huli, 18,065 (33 percent) as Duna, 2926 (5 percent) as Hewa, 425 as Febi, 335 as Bogaia, and 226 as Awi speakers. This ethnic mix has made for fiercely contested parliamentary elections in the past, with all the past candidates being of either Huli or Duna extraction. Except for the periods 1977-1982 and 2003-2004 the sitting member has always been Huli. This is not altogether surprising as the Huli outnumber the Duna 2:1 and as such command a huge electoral advantage within the electorate.

\section{A history of violence}

Since 1997, when guns were first used to menace voters in Koroba-Lake Kopiago Open electorate (Robinson 2002), violence and intimidation have figured prominently in elections in this part of the Southern Highlands (see also Haley 2002, 2004). In 1997 for instance, guns were used to influence electoral outcomes by controlling the voting at particular polling stations and a helicopter carrying the then sitting member, Herowa Agiwa, was fired upon by supporters of an opposing candidate during the campaign period. The latter incident resulted in over US\$300,000 damage to the Hevilift helicopter (Haley 2004:19).

By 2002 guns and violence were widespread: election-related deaths were reported during the campaign period and in the aftermath of the elections; Ben Peri (a high profile Duna candidate) was kidnapped and held for ransom; another candidate armed his own militia; all air traffic was suspended following threats that planes would be shot out of the sky; and voters throughout the electorate were threatened and intimidated by candidates and their supporters (Haley 2004). These factors contributed to the failure of the 2002 elections.

Post 2002, elections in Koroba-Lake Kopiago have involved huge investments in security. Two thousand additional security personnel were deployed under a national call-out during the 2003 supplementary elections, 800 additional police and Papua New Guinea Defence Force (PNGDF) personnel were engaged during the 2006 Koroba-Lake Kopiago by-election security operations (Haley 2006), and an additional 2500 security personnel were deployed to the Southern Highlands in 2007. Despite the huge security presence and the imposition of a state of emergency followed by special police operations in the 10 months leading up to the elections, guns remained present in the electorate in significant numbers.

3 This figure has been calculated from the 1990 census figures using the national population growth rate of 2.7 percent per annum. The 2000 national census figures for the Southern Highlands are highly suspect, having been grossly inflated (see Haley 2004). 
Indeed, members of the Koroba-Lake Kopiago observer team reported seeing both high-powered and homemade weapons throughout the electorate and a relative abundance of black market ammunition at pre-state-of-emergency prices (see chapter 8 and Haley and Muggah 2006). They also reported road closures, intermittent election-related violence; and an election-related death in the leadup to polling at Koroba. One observer was threatened and warned away from a polling station at Harereke by men armed with bush knives, and the brother of another observer was killed at Koroba. That said, there were few overt displays of weapons at polling places, and guns were not openly used to intimidate and influence the vote as they had been in 1997 and 2002.

\section{A history of fraud and malpractice}

I have documented in considerable detail the fraudulent electoral practices that have characterized elections in the Koroba-Lake Kopiago electorate over the past decade (Haley 2002, 2004 and 2006). The 2007 election, like those of the past decade, lacked integrity and was marred by widespread cheating, fraud and malpractice. Key strategies effectively utilized in the past were once again employed. These included inflating the electoral roll, having electoral officials removed and replaced, diverting and impounding ballot boxes, using excess ballot papers, pre-marking ballot papers, and voting multiple times. Much of the malpractice witnessed in 2007, which is detailed in the following sections of this chapter, can be attributed to the poor state of the new electoral roll.

\section{Key electoral personnel}

One of the ways candidates sought to control election outcomes in 2007 was through control of key election officials. This proved to be a particularly ineffective strategy as in-fighting between key election officials detrimentally impacted upon their performance and saw them effectively paralysed at key junctures. As a consequence, the security personnel stepped in, assuming responsibility for critical aspects of the election preparations (see chapter 8 ).

Without exception, observers were critical of the key electoral personnel engaged to conduct the elections in Koroba-Lake Kopiago electorate. They were particularly critical of the Southern Highlands election manager, David Wakias, considering him to be both ineffectual and partisan. They observed that he could rarely be found in his office, 'spent most of his time roaming around in his hire car' and seemed 'happy to let the politically appointed provincial returning officer-Charles Ipa-run the show'. Another observer had this to say: 'He is a 
good man, good at making excuses and delaying things. For example he didn't allow people to check their names on the electoral roll to see whether they were enrolled or not'.

Observers were equally critical of the returning officer and assistant returning officers. They too were considered partisan, politically compromised, and unfit to undertake their appointed rolls. The returning officer, Denny Hongai, and the assistant returning officers for North Koroba (Haddick Apiako/Sakopa), South Koroba (Don Piru/Palabu) and Awi/Lokayu (Jackson Kenamu) had all held their positions since 2006, and in particular had run the 2006 Koroba-Lake Kopiago by-election. On this basis, one might have assumed a degree of confidence and the knowledge, skills and competency to run an election. Unfortunately this proved not to be the case.

There were problems too at Lake Kopiago. In the lead-up to the election the assistant returning officer's position changed hands several times. Steven Pauwini, the former council executive officer, had held the position during 2006. Following poor performance during the 2006 Koroba-Lake Kopiago byelection he was replaced. Richard Bei/Pelaku took over the position of assistant returning officer for Lake Kopiago in early 2007_ and was observed to be far more competent than his predecessor. On 23 March 2007, however, Bei's appointment was revoked and Jackson Hewape was appointed in his place (National Gazette No. G63, 19 April 2007). Hewape's appointment was subsequently revoked, and on 14 May 2007, Bei was reappointed to the position. There were rumours that Hewape was again reappointed to the position in mid-June, but no evidence of this could be found in the National Gazette. In any event both men continued to argue that they were the duly appointed assistant returning officer, both accompanied the ballot boxes and ballot papers to Lake Kopiago, both sought to direct polling operations at Lake Kopiago on polling day, and both were present in the counting room. It is understood that in the week before polling the election manager instructed both men to work together, and that he appointed Jackson Hewape as assistant to the Lake Kopiago assistant returning officer. Needless to say this caused much confusion in the electorate and hampered planning and performance. It also caused considerable consternation in the counting room, resulting in much discussion about the integrity of the 19 Lake Kopiago ballot boxes, and saw scrutineers for the various Huli candidates seek to have the boxes excluded from the count.

\section{Electoral rolls (past and present)}

In the wake of the 2002 election, new electoral rolls were created for each of Papua New Guinea's 109 electorates. On the face of it the new Koroba-Lake 
Kopiago electoral roll, which resulted from a re-registration exercise undertaken in late 2005, appears more accurate than those used in 1997, 2002, and 2003. The new roll, for instance, has only 48,739 names as compared with the 2002 roll which listed 60,300 enrolled voters. Appearances can be deceptive though. In the Koroba-Lake Kopiago case the electoral roll is grossly inaccurate, with many more enrolled voters than eligible citizens (Table 21.1).

Table 21.1: Comparison of electoral rolls and votes cast in Koroba-Lake Kopiago Open electorate, 1992 to 2007

\begin{tabular}{lrrrrr}
\hline Election & $\begin{array}{r}\text { Total } \\
\text { population }\end{array}$ & $\begin{array}{r}\text { Expected } \\
\text { enrolments }\end{array}$ & $\begin{array}{r}\text { Actual } \\
\text { enrolments }\end{array}$ & $\begin{array}{r}\text { Votes } \\
\text { cast }\end{array}$ & $\begin{array}{r}\text { Votes as percent of } \\
\text { expected enrolments }\end{array}$ \\
\hline 1992 & 36,920 & 18,460 & na & 14,264 & 77 \\
1997 & 42,180 & 21,090 & 40,127 & 32,874 & 156 \\
2003 & 49,490 & 24,745 & 60,300 & 42,595 & 172 \\
2006 & 53,610 & 26,800 & 48,778 & 41,029 & 153 \\
2007 & 55,060 & 27,530 & 48,739 & 45,020 & 164 \\
\hline
\end{tabular}

$a$ The expected enrolment is held to be 50 percent of the total projected electorate population, calculated from the 1990 census figures using the national population growth rate of 2.7 percent per annum.

As outlined in Table 21.1, enrolled voters have far exceeded the number of eligible citizens in the Koroba-Lake Kopiago electorate for more than a decade now (see Haley 2002, 2004), with the original inflation of the roll dating back to the 1997 elections. In 1992 14,264 votes were counted. In 1997 there was a twofold increase in the number of ballots cast, with 32,724 votes allowed (Haley 2002:134). Since then, over 40,000 votes have been cast at each election.

Based on population figures projected from the 1990 census, and confirmed in many wards by a household census conducted in 1997 (Haley and Robinson 1998; Robinson and Haley 1998a, 1998b) it is estimated that there should have been no more than 27,500 eligible voters in the Koroba-Lake Kopiago electorate in 2007. The common roll created for the 2007 election, however, contained 48,739 names, and is replete with gross irregularities, including highly inflated voter numbers in at least one-quarter of proclaimed wards; thousands of eligible citizens disenfranchised and not on the roll or allocated to the wrong wards; thousands of under-age voters, enrolled by virtue of fictitious birth dates; and thousands of duplicate entries. ${ }^{4}$

In order to get a fuller sense of the problems associated with the new electoral roll, the Koroba-Lake Kopiago observer team undertook a careful analysis of

4 For specific examples refer to the 2006 Koroba-Lake Kopiago by-election observation report (Haley 2006). Many of the irregularities identified therein were not rectified prior to the 2007 election. For the most part this had to do with the poorly implemented verification exercise, which saw a net reduction of only 39 names from the 2006 by-election roll. 
ward rolls within the Lake Kopiago LLG area. ${ }^{5}$ This was done using census material collected in the past (Haley and Robinson 1998; Robinson and Haley 1998a, 1998b), on the basis of our own knowledge, and in consultation with community leaders. This close examination of the ward rolls for the 19 wards within Lake Kopiago LLG - one of four LLGs within Koroba-Lake Kopiago electorate - revealed that only half (50.2 percent) of the 10,351 enrolled voters were actually eligible to enrol. Examination of the ward rolls for Lake Kopiago also revealed the following irregularities:

- highly inflated voter numbers in many wards

- entire villages and hamlets assigned to the wrong wards

- 2426 (23.4 percent) enrolled voters who were not known in the ward

- 1197 (11.6 percent) under-age voters enrolled with fictitious birth dates

- 744 (7.2 percent) enrolled voters who did not meet residency requirement

- 664 (6.4 percent) duplicate entries

- 243 (2.3 percent) deceased voters who miraculously re-registered

- at least 735 eligible citizens who do not appear on the new electoral roll.

Put simply, there are gross irregularities with the electoral roll across the entire electorate. As well as wards in which enrolments are highly inflated, there are wards which are under-enrolled, and over-enrolled wards which are missing significant numbers of eligible citizens. In some cases this seems to have been due to administrative errors but in other cases because enterprising candidates successfully managed to ensure that their opponents' supporters were disenfranchised. In Koroba-Lake Kopiago, and indeed elsewhere in the Southern Highlands, observers identified whole families and clans which were disenfranchised by being placed in the wrong wards or by being left off the roll completely. These irregularities meant that while some people were not included on the roll at all, others were included from two to six times.

Based on the above analysis the Lake Kopiago LLG roll should have included some 6000 names: the 5196 correctly enrolled people $(50.2$ percent of 10,351$)$ plus the $735+$ eligible citizens who were missing altogether. If one takes the 1990 census population for Lake Kopiago LLG, which is predominantly Duna speaking, and projects forward to 2007 using the national population growth rate, an eligible voting population of 6200 should have been expected. On this basis the LLG was over-enrolled by 67 percent at the time of the 2007 election. Using the same methodology, the North Koroba and South Koroba LLGs, which are

5 In all there are 19 wards in the Lake Kopiago LLG. One ward comprises Bogaia speakers, another comprises Awi speakers, four could be considered ethnically Hewa and the remaining 13 are Duna wards. 
ethnically Huli, were over-enrolled by 79 percent and 84 percent respectively, ${ }^{6}$ while Auwi-Pori LLG, where voters are Duna speaking, was over-enrolled by 71 percent. Overall, the Duna-speaking parts of the electorate are over-enrolled by 68 percent while the Huli-speaking parts of the electorate were over-enrolled by 82 percent. This amplifies the electoral advantage the Huli command, and delivers to them nearly 15,000 additional ballot papers/votes, as compared to the 6400 additional ballot papers/votes available to the Duna.

Both the enrolment and verification exercises were highly problematic in the Koroba-Lake Kopiago Open electorate. Very few people actually saw the enrolment teams and even fewer filled out a claim for enrolment form. Correct procedure dictates that eligible citizens should have completed and signed a claim for enrolment form, in order to re-enrol. Observers across the electorate reported that teams of local men were employed to complete, sign and witness the forms on behalf of the wider community. In doing so these enumerators knowingly witnessed and signed off on thousands of forms in which false claims or declarations had been made. In the vast majority of cases there was no excuse for witnessing false declarations as the local men employed as village enumerators were from the wards in which they undertook the enrolment exercise and would have known who was under-age, who was long absent from the electorate (that is, those who did not meet the legislatively proscribed residency requirements), ${ }^{7}$ and which of the would-be electors were actually dead.

Across the electorate claims of political interference in the enrolment process, and claims that not enough forms were sent out were regularly encountered. There is seemingly some merit in these allegations in that there is huge overenrolment in some wards and significant under-enrolment in others. Haredege ward, one of the most-populous wards in Lake Kopiago LLG is a case in point. Based on the 1990 census, a voting population of 463 was expected in 2007; however, the 2007 ward roll contained only 158 names, thus two-thirds of eligible voters in the ward were disenfranchised.

Observations made during the 2007 domestic observation reveal that the wider community was not complicit in the fraud that saw them placed on the roll multiple times. Indeed the vast majority of people did not personally place

\footnotetext{
6 Expected enrolments in North Koroba and South Koroba were 8186 and 9922 respectively, while actual enrolments were 14,654 and 18,228 .

7 Section 55(1) of the Organic Law on National and Local-Level Government Elections requires that a person making a claim for enrolment must have 'resided in the area of an electorate for a period of not less than six months immediately preceding the date of his [or her] claim for enrolment' (s. 51(1)(a)). This means that clan members residing outside the electorate in the six months leading up to the enrolment exercise were not eligible to be enrolled. Linked to this, electors were required to be present at the time of enrolment. Page 7 of the Electoral Roll Training Manual outlines this aspect of the enrolment procedure in bold font, saying, 'The elector must sign the enrolment form personally, or make their mark. An enrolment form cannot be signed by another person on behalf of the elector'. Where this did not happen procedure was clearly breached.
} 
themselves on the roll, and prior to the civic and electoral awareness undertaken by Ima Kelo between November 2006 and April 2007 (see chapter 20) many were not even aware that new rolls had been created. Of the 12 domestic observers who live in the Koroba-Lake Kopiago electorate and were eligible to enrol, only one had completed a claim for enrolment form, yet they were all enrolledand most were enrolled multiple times. At least three of the domestic observers appeared on the roll three separate times. A survey of 200 voters, undertaken during the campaign period, further revealed that only 12 people (seven men and five women), 6 percent of the survey respondents, had actually completed a 'claim for enrolment' form.

Like the enrolment exercise, the verification exercise was highly problematic. The rolls were not publicly displayed in the wards or in Kopiago sub-district. Our Koroba observers reported that the rolls were on display at Koroba district office but they disagree over how long for-reports ranging from one to seven days. In Mendi, the provincial headquarters, the rolls went on public display only 48 hours before the issue of writs - so that there was only a very small window of opportunity for voters to check whether their name appeared on the roll. For those who managed to check the roll, the exercise proved futile, because amendments made during the 48-hour window were not reflected on the final rolls. One of the observers, Kenny Kendoli, travelled to Mendi and sought to have his multiple entries removed. He annotated the verification roll in the presence of the election manager, and the observation coordinator, yet he still appeared on the electoral roll in three places. At the same time, he sought to have his four under-age children removed from the roll, by annotating their entries to the effect that they were under-age. All four children remained on the roll. They were included on the roll without their parents' knowledge or consent, and all appear with fictitious birthdates (Table 21.2).

Table 21.2: Examples of under-age voters with fictitious birth dates, Koroba-Lake Kopiago Open electorate

\begin{tabular}{|c|c|c|c|c|c|c|c|c|}
\hline $\begin{array}{l}\text { Ward } \\
\text { name }\end{array}$ & Elector ID & $\begin{array}{c}\text { Last } \\
\text { name }\end{array}$ & $\begin{array}{l}\text { First } \\
\text { name }\end{array}$ & Sex & $\begin{array}{l}\text { Birth date } \\
\text { on roll }\end{array}$ & Occupation & $\begin{array}{c}\text { Actual } \\
\text { birth date }\end{array}$ & Age \\
\hline Hirane & 76014203 & Yuwi & Rodney & $M$ & $1 \mathrm{Dec} 1983$ & Student & $\begin{array}{c}\text { O2 Nov } \\
1989\end{array}$ & 17 \\
\hline Hirane & 76014262 & Yuwi & Jassin & M & 12 Feb 1985 & Student & $\begin{array}{c}20 \text { Sept } \\
1992\end{array}$ & 14 \\
\hline Hirane & 76014314 & Yuwi & Melo ${ }^{a}$ & $M$ & 5 Oct 1987 & Student & $\begin{array}{c}19 \text { Oct } \\
1995\end{array}$ & 11 \\
\hline Hirane & 76000459 & Kenny & Mero & $M$ & $10 \mathrm{Feb}$ & Student & $\begin{array}{c}19 \text { Oct } \\
1995\end{array}$ & 11 \\
\hline Hirane & 76014377 & Yuwi & Bonica & $\mathrm{F}$ & 6 May 1989 & Student & $\begin{array}{l}\text { ?? Oct } \\
1999\end{array}$ & 7 \\
\hline
\end{tabular}

a Melo, the youngest son, is included on the roll twice, under two different spellings of his name, and under both his father's birth name and Christian name. 
Two other observers collectively made several hundred corrections to various Lake Kopiago rolls on display in Mendi, in order to move disenfranchised voters to their correct wards. Similarly, these amendments were not reflected on the final rolls.

Despite the fact that the rolls were not publicly displayed as they should have been, the assistant returning officers, with assistance from local enumerators, undertook a roll-cleansing exercise of sorts. In the Kopiago and Awi/Logayu LLG areas this saw enrolments decrease substantially, and in South Koroba it saw enrolments increase (Table 21.3).

Table 21.3: Summary of enrolments, Koroba-Lake Kopiago Open electorate, 2006 and 2007

\begin{tabular}{lccc}
\hline LLG area & $\begin{array}{c}\text { 2006 By-election roll, } \\
\text { (verification roll) } \\
\text { 22 June 2006 }\end{array}$ & $\begin{array}{c}\text { 2007 Electoral roll, } \\
\text { (final roll) } \\
\text { May 2007 }\end{array}$ & Variation \\
\hline Kopiago & 11,038 & 10,351 & $6 \%$ decrease \\
Auwi-Pori & 6,962 & 5,506 & $21 \%$ \\
North Koroba & 14,824 & 14,654 & $\begin{array}{c}\text { decrease } \\
\text { South Koroba }\end{array}$ \\
Total & 15,954 & 18,228 & $14 \%$ increase \\
\hline
\end{tabular}

The assistant returning officers for Kopiago and Awi/Logayu alleged a conspiracy on the part of the returning officer, claiming that while the North and South Koroba assistant returning officers were given plenty of forms, they got only a handful and so were not able to enrol missing voters during the verification exercise.

Table 21.4 compares actual enrolments with expected enrolments, at the ward level, based on the 1990 census. ${ }^{8}$ It shows significant over-enrolment in a large number of Huli-speaking wards, and makes evident that enrolments in several already over-enrolled wards increased even further during the verification process, which took place between the 2006 by-election and the 2007 general election. Enrolments in Tumbite ward, for example, increased from 1299 in 2006 to 2586 in 2007, while enrolments in Pubulumu 1 and 2 increased from 796 to 2485. At Tumbite inflation of the roll was achieved by duplication using different but similar spellings of the same name and by giving different birth years for

\footnotetext{
8 The table is based on an investigative approach developed by Thelma Oberdorf, a specialist roll adviser from the Australian Electoral Commission, to help election managers identify and prioritise ward rolls that required cleaning. Oberdorf's approach involved comparing expected ward enrolments, calculated using the age data contained within the 2000 census, with actual ward enrolments. Given that the 2000 census figures for Southern Highlands Province are generally regarded as highly suspect, I have based my calculations on the 1990 census figures.
} 
each entry (see Table 21.13 in the appendix of this chapter for examples). Among the Huli, ' $\mathrm{K}$ ' and ' $\mathrm{G}$ ', ' $\mathrm{P}$ ' and ' $\mathrm{B}$ ' and ' $\mathrm{Y}$ ' and ' $\mathrm{J}$ ' are often used interchangeably. These regular variations form the basis of the duplication identified.

Table 21.4: Comparison of over-enrolled wards in North Koroba and South Koroba, Koroba-Lake Kopiago Open electorate

\begin{tabular}{|c|c|c|c|c|c|c|c|c|}
\hline Ward(s) & LLG & $\begin{array}{r}\text { Census } \\
1990\end{array}$ & $\begin{array}{r}\text { Expected } \\
\text { ward } \\
\text { enrolmt }^{\mathrm{a}}\end{array}$ & $\begin{array}{r}\text { Ward } \\
\text { enrolmt } \\
2006\end{array}$ & $\begin{array}{r}\text { Ward } \\
\text { percent } \\
2006\end{array}$ & $\begin{array}{r}\text { Ward } \\
\text { enrolmt } \\
2007\end{array}$ & $\begin{array}{r}\text { Ward } \\
\text { percent } \\
2007\end{array}$ & $\begin{array}{r}\text { Votes } \\
\text { cast } \\
2007\end{array}$ \\
\hline Tumbite & Sth Koroba & 877 & 690 & 1299 & 188 & 2586 & 375 & 2583 \\
\hline Teria $1 \& 2$ & Nth Koroba & 488 & 384 & 1289 & 336 & 1419 & 370 & 888 \\
\hline Pubulumu $1 \& 2$ & Sth Koroba & 1182 & 930 & 796 & 86 & 2485 & 267 & b2499 \\
\hline Betege $1 \& 2$ & Nth Koroba & 670 & 527 & 1099 & 209 & 1171 & 222 & 1190 \\
\hline Andiria $1 \& 2$ & Sth Koroba & 619 & 487 & 1175 & 241 & 1025 & 210 & 979 \\
\hline Maria & Sth Koroba & 720 & 566 & 1022 & 181 & 1161 & 205 & 1061 \\
\hline Ereiba $1 \& 2$ & Nth Koroba & 819 & 644 & 1441 & 224 & 1312 & 204 & 881 \\
\hline Gunu $1 \& 2$ & Sth Koroba & 671 & 528 & 1172 & 222 & 1056 & 200 & 890 \\
\hline Topi & Nth Koroba & 156 & 123 & 250 & 203 & 238 & 193 & 243 \\
\hline Aiyenda & Nth Koroba & 372 & 293 & 619 & 211 & 549 & 187 & 531 \\
\hline Kenamo & Nth Koroba & 261 & 205 & 416 & 203 & 382 & 186 & 386 \\
\hline Kagoma & Nth Koroba & 577 & 454 & 739 & 163 & 829 & 183 & 797 \\
\hline Humburu $1 \& 2$ & Sth Koroba & 746 & 587 & 1099 & 187 & 1068 & 182 & 1079 \\
\hline Magara $1 \& 2$ & Sth Koroba & 946 & 744 & 1567 & 211 & 1252 & 168 & 1264 \\
\hline Hujanoma $1 \& 2$ & Nth Koroba & 962 & 757 & 993 & 131 & 1241 & 164 & 1254 \\
\hline Kakarene $1 \& 2$ & Sth Koroba & 1250 & 983 & 1616 & 164 & 1495 & 152 & 1298 \\
\hline Pandu & Sth Koroba & 603 & 474 & 599 & 126 & 721 & 152 & 612 \\
\hline Hedemari $1 \& 2$ & Sth Koroba & 914 & 719 & 1148 & 160 & 1080 & 150 & 1084 \\
\hline Mbuli & Sth Koroba & 974 & 766 & 1191 & 155 & 1141 & 149 & 1143 \\
\hline Levani & Nth Koroba & 716 & 563 & 848 & 151 & 834 & 148 & 839 \\
\hline Piagonga $1 \& 2$ & Nth Koroba & 685 & 539 & 799 & 148 & 769 & 143 & 778 \\
\hline Tangimapu & Sth Koroba & 763 & 600 & 878 & 146 & 854 & 142 & 859 \\
\hline Yatimali & Nth Koroba & 816 & 642 & 895 & 139 & 892 & 139 & nil \\
\hline Kelabo $1 \& 2$ & Nth Koroba & 702 & 552 & 948 & 172 & 749 & 136 & 691 \\
\hline Hauwinda & Nth Koroba & 326 & 256 & 348 & 136 & 338 & 132 & 346 \\
\hline Erebo & Sth Koroba & 673 & 530 & 668 & 126 & 649 & 122 & 653 \\
\hline Jaguabi & Nth Koroba & 605 & 476 & 636 & 134 & 578 & 121 & 576 \\
\hline Warukumu & Nth Koroba & 620 & 468 & 569 & 117 & 567 & 121 & 564 \\
\hline
\end{tabular}

a The expected ward enrolment in this case was held to be 50 percent of the total projected population and was calculated from the 1990 census figures using the national population growth rate of 2.7 percent per annum.

$b$ This represents four more papers than were collectively issued to these two polling stations, although in fact nine additional ballot papers found their way into the Pumbulumu 1 ballot box. 
Based on the age data in the 2000 census and projections from the 1990 census, there should be no more than 600-700 eligible voters in Tumbite and around 900 voters in Pubulumu 1 and 2 combined. In 2007, enrolments at Tumbite and Pubulumu were three to four times greater than they should have been. These three wards formed the core of Father Matthias Olape's base vote. Indeed, he picked up 5008 of the 7978 first preference votes he received from these three wards alone. Olape was the National Alliance endorsed candidate in 2006 and People's Party endorsed candidate in the $2007 .^{9}$

Exceptionally high enrolments were also found in the base votes of the sitting member of parliament (MP) (John Kekeno) and the former MP (Herowa Agiwa), and these likewise increased in the 12 months between the 2006 by-election and the 2007 election. Perhaps not surprisingly, it is the most over-enrolled wards that demonstrated the highest degree of voting solidarity, with more than 90 percent of the votes cast typically going to a single candidate. This suggests that inflation of the roll in these wards was deliberate and intended to benefit particular candidates (Table 21.5). A consideration of enrolments over time seemingly confirms this. Over-enrolments in individual wards can be shown to be linked to the presence of a strong local candidate. For example, when Petrus Thomas contested the 2003 supplementary elections, enrolments at Aiyuguni and Wagia-Pogolaia, his mother's and father's home areas respectively, went up from 540 (1997 roll) to over 1300 (in 2003), and from 336 (1997 roll) to 582 (in 2006). Similarly when John Kekeno contested the 2006 by-election, enrolments at Warukumu (Warukumu and Kenamu) went up from 599 to 911 . When he ran again in 2007 they increased further, rising to 945.

Similar patterns are evident elsewhere in the electorate. For example, enrolments at Maria and Humburu rose significantly when Matiabe contested the 2006 byelection: enrolments at Maria rose from 883 in 1997 to 1018 in 2006 and 1161 in 2007, while those at Humburu increased from 840 in 1997 to 1092 in 2006. The inflation of the Pubulumu roll likewise coincided with Olape contesting the seat. Pre-Olape, the enrolment for Pubulumu totalled 1062 in 1997; in 2003 it rose to over 1200 and then to 2485 in 2007.

9 Throughout the electorate voters consistently alleged that the assistant returning officer for South Koroba was a diehard Father Matthias supporter. 


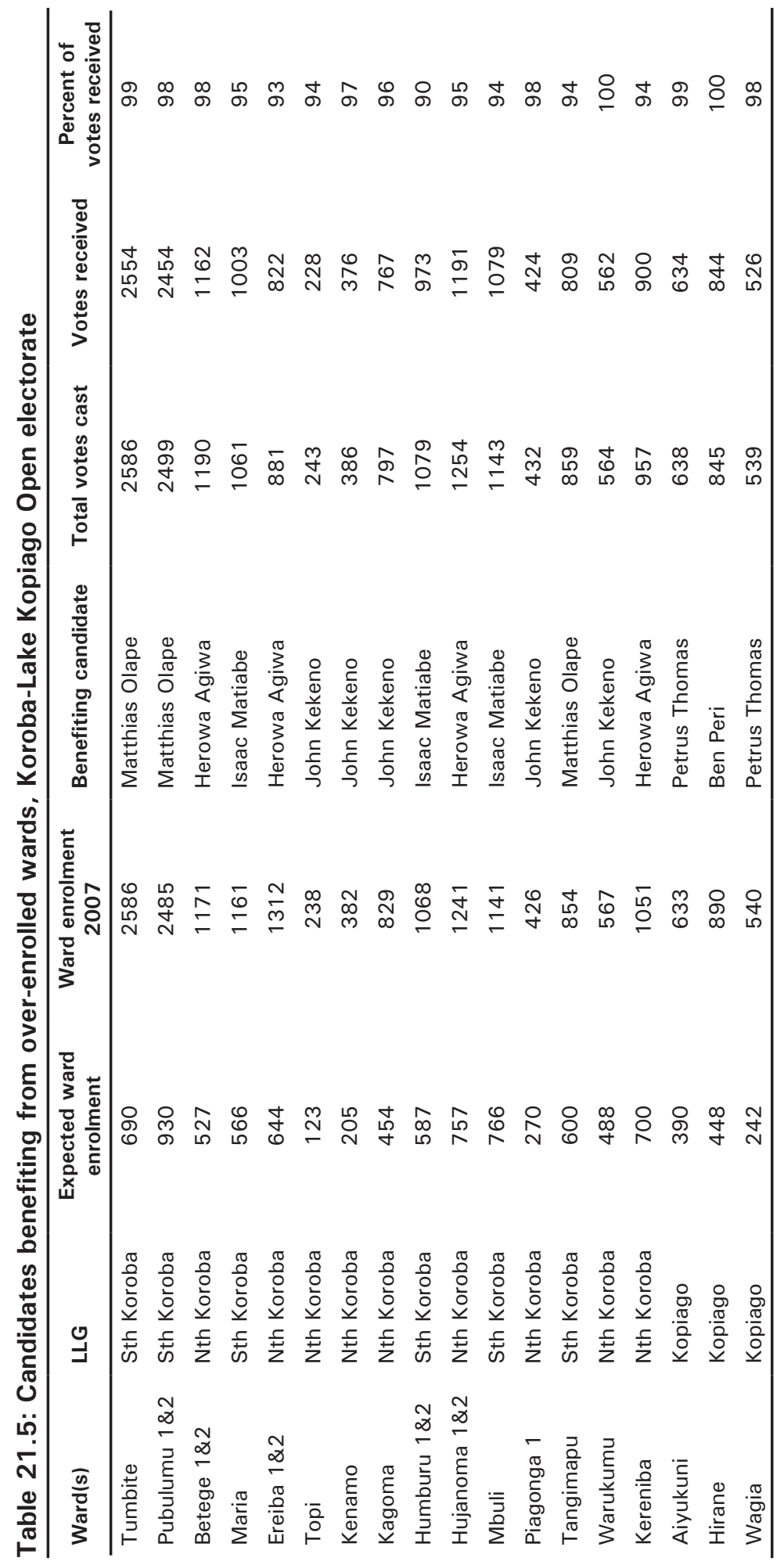


Another common practice the Huli have employed to boost their enrolments concerns splitting old census units into two separate wards. Over the past decade, 15 locally constituted communities were split in this way. Such paired wards typically bear the same name. In North Koroba these paired wards include Betege 1 \& 2, Ereiba 1 \& 2, Hujanoma 1 \& 2, Kelabo 1 \& 2, Kereniba 1 \& 2, Piagonga $1 \& 2$, and Teria $1 \& 2$, and in South Koroba they include Andiria 1 \& 2, Gunu 1 \& 2, Hedemari 1 \& 2, Humburu 1 \& 2, Kakarene 1 \& 2, Magara 1 \& 2, and Pabulumu $1 \& 2$. In each of these paired wards enrolments are significantly inflated, with many individuals appearing on both ward rolls. In 2006 and 2007 the polling places for these paired wards were set up side by side and voters were repeatedly observed to move between polling stations, and to vote at both, often multiple times.

\section{The 2007 candidates and their alliances}

Seventeen candidates contested the Koroba-Lake Kopiago Open seat in 2007. This was a smaller field than in 2002, when 19 candidates contested, and a smaller field than the 2006 by-election, which had been contested by a record 20 candidates. Of the 17 candidates, 11 had contested this seat previously, and nine had contested the 2006 by-election, which had been conducted under LPV. No women contested the seat. For the first time ever, there were more Duna candidates than Huli candidates (Table 21.6), and as in 1997 and 2002 cultural identity and ethnicity figured importantly in campaigning.

Table 21.6: Ethnicity of candidates, Koroba-Lake Kopiago Open electorate, 1997 to 2007

\begin{tabular}{lccccc}
\hline Election & $\mathbf{1 9 9 7}$ & $\mathbf{2 0 0 2}$ & $\mathbf{2 0 0 3}$ & $\mathbf{2 0 0 6}$ & $\mathbf{2 0 0 7}$ \\
\hline Total candidates & 13 & 19 & 12 & 20 & 17 \\
Huli candidates & 7 & 13 & 10 & 12 & 8 \\
Duna candidates & 6 & 6 & 2 & 8 & 9 \\
\hline
\end{tabular}

Table 21.7 provides summary information concerning the 17 candidates who contested the 2007 election. Of these, six were serious contenders, namely: the sitting MP John Kekeno (MP 2006-2007), Petrus Thomas (MP 2003-2004), Ben Peri (runner-up 2003 and 2006), Father Mathias Olape, Herowa Agiwa (MP 19922002) and Isaac Matiabe - brother of the late Aruru Matiabe (MP 1982-1992). 
Table 21.7: Candidate summary, Koroba-Lake Kopiago Open electorate

\begin{tabular}{|c|c|c|c|c|c|}
\hline No. & Candidate & Ethnicity & Area & LLG & Previous elections contested \\
\hline 10 & Paul Pora Wasdok & Huli & Koroba & Sth Koroba & \\
\hline 11 & $\begin{array}{l}\text { Dokta Philip } \\
\text { Pakalu }\end{array}$ & Duna & Kopiago & Kopiago & 1992 \\
\hline 12 & $\begin{array}{l}\text { Thomas Tupia } \\
\text { Ape }\end{array}$ & Duna & Kopiago & Kopiago & \\
\hline 13 & Herowa Agiwa & Huli & Fugua & Nth Koroba & $\begin{array}{l}\text { Successful 1992, 1994, } 1997 \\
\text { Contested 2002, 2003, } 2006\end{array}$ \\
\hline 14 & Agiru Hole & Huli & Tangi & Nth Koroba & \\
\hline 15 & $\begin{array}{l}\text { Allan Limbawi } \\
\text { Mone }\end{array}$ & Duna & Kopiago & Kopiago & \\
\hline 16 & $\begin{array}{l}\text { Nane Petrus } \\
\text { Thomas }\end{array}$ & Duna & Kopiago & Kopiago & $\begin{array}{l}2002,2003,2006 \\
\text { Successful } 2003\end{array}$ \\
\hline 17 & Daniel Mapira & Huli & Koroba & Sth Koroba & 1982,2006 \\
\hline 18 & Ben Epe Peri & Duna & Kopiago & Kopiago & $\begin{array}{l}\text { 1992, 1994, 1997, } 2002 \\
\text { Runner-up in } 2003 \text { \& } 2006\end{array}$ \\
\hline 19 & Paiyale Elo & Duna & Kopiago & Kopiago & $\begin{array}{l}\text { 1977, 1982, 1987, 1992, } \\
\text { 1994, 1997, } 2002 . \\
\text { Successful 1977 }\end{array}$ \\
\hline 20 & Isaac Matiabe & Huli & Maria & Sth Koroba & 1994, 2006 \\
\hline 21 & $\begin{array}{l}\text { Waa Alfred } \\
\text { Akope }\end{array}$ & Huli & Koroba & Nth Koroba & \\
\hline 22 & $\begin{array}{l}\text { Ronald Kendopa } \\
\text { Kulakua }\end{array}$ & Duna & Kopiago & Kopiago & 2006 \\
\hline 23 & $\begin{array}{l}\text { Mcnene Mai } \\
\text { Paiale Elo }\end{array}$ & Duna & Kopiago & Kopiago & \\
\hline 24 & Matthew Magaye & Duna & Auwi & Awi Logaiyu & $\begin{array}{l}\text { 1992, 1997, 2002, } 2006 \\
\text { Runner-up in } 1992 \& 1997\end{array}$ \\
\hline 25 & $\begin{array}{l}\text { John Kekeno } \\
\text { Kelewa }\end{array}$ & Huli & Tangi & Nth Koroba & Successful in 2006 \\
\hline 26 & Mathias Olape & Huli & Pureni & Sth Koroba & 2002, 2003, 2006 \\
\hline
\end{tabular}

All six candidates scored over 4500 first preference votes and were the last six candidates left in the race. The same six had filled the top six positions in the 2006 by-election, and Thomas, Peri, Olape and Agiwa had filled the top four positions in the 2003 supplementary elections. All six candidates benefited, to some extent, from the over-enrolments detailed in the last section (see Table 21.5), although some more than others.

Agreements and alliances were formed between several candidates, with some, namely Ben Peri and Matthew Magaye, and Paiele Elo and Ronald Kulakua, agreeing to share preferences, and others, particularly the weaker candidates, apparently standing to split the votes of stronger candidates. The reputed alliances and shared histories of the candidates are summarised in Table 21.8. 
Election 2007: The Shift to Limited Preferential Voting in Papua New Guinea

Table 21.8: Reputed alliances and shared histories, Koroba-Lake Kopiago Open electorate

\begin{tabular}{|c|c|}
\hline Candidate & Alliances and shared histories \\
\hline \multirow[t]{2}{*}{ Paul Pora Wasdok } & no known alliances with other candidates \\
\hline & campaigned only for minor preferences and to be known for 2012 \\
\hline \multirow[t]{2}{*}{ Phillip Dokta Pakalu } & no known alliances with other candidates \\
\hline & $\begin{array}{l}\text { contested in 2007, because his wife had contested the } 2006 \text { by- } \\
\text { election }\end{array}$ \\
\hline \multirow[t]{2}{*}{ Thomas Tupia Ape } & close friend of Matthew Magaye \\
\hline & $\begin{array}{l}\text { thought to be standing to split Ben Peri and Petrus Thomas' vote } \\
\text { and to capture preferences for Magaye }\end{array}$ \\
\hline \multirow[t]{5}{*}{ Herowa Urape Agiwa } & former member (1992-2002) \\
\hline & former patron of John Kekeno, although reputed to have fallen out \\
\hline & longstanding political opponent of Ben Peri \\
\hline & reputed to have orchestrated Ben Peri's kidnapping in 2002 \\
\hline & had supported Matthew Magaye in 1997 to split Peri's vote \\
\hline \multirow[t]{2}{*}{ Agiru Hole } & widely reputed to have been funded by Ben Peri \\
\hline & thought to be standing to split John Kekeno's vote \\
\hline \multirow[t]{5}{*}{ Allen Limbawi Mone } & a career public servant/administrator \\
\hline & $\begin{array}{l}\text { former brother-in-law to Ben Peri, with whom he has been in } \\
\text { dispute over non-payment of bride-price }\end{array}$ \\
\hline & key supporter of Matthew Magaye in 1992 and 1997 \\
\hline & refused political appointment from Agiwa following 1992 elections \\
\hline & key supporter of Petrus Thomas in 2003 \\
\hline \multirow[t]{4}{*}{ Nane Petrus Thomas } & former member (2003-2004) \\
\hline & related to but a political opponent of Ben Peri \\
\hline & related to Ronald Kendopa Kulakua \\
\hline & previously supported by Matthew Magaye and Alen Mone in 2003 \\
\hline \multirow[t]{2}{*}{ Daniel Mapiria } & former chairman of the National Gaming Board \\
\hline & no known alliances with other candidates \\
\hline \multirow[t]{5}{*}{ Ben Epe Peri } & closely related to, but a political opponent of, Petrus Thomas \\
\hline & related to Ronald Kendopa Kulakua \\
\hline & $\begin{array}{l}\text { signed a memorandum of understanding with Matthew Magaye to } \\
\text { exchange preferences }\end{array}$ \\
\hline & classmate of Isaac Matiabe; the two were said to have an alliance \\
\hline & $\begin{array}{l}\text { close associate of Anderson Agiru, President of the United } \\
\text { Resources Party and former Southern Highlands Province governor } \\
\text { (1997-2002) }\end{array}$ \\
\hline \multirow[t]{5}{*}{ Paiele Elo } & former member (1977-1982) \\
\hline & widely reputed to have been funded by John Kekeno \\
\hline & $\begin{array}{l}\text { thought to be standing to split Ben Peri's and Petrus Thomas's } \\
\text { votes }\end{array}$ \\
\hline & encouraged supporters to give their preferences to Kulukua \\
\hline & $\begin{array}{l}\text { closely aligned with the former Southern Highlands Province } \\
\text { governor, Hami Yawari }\end{array}$ \\
\hline
\end{tabular}


21. Results at any Cost? The Legacy of 2002 in Koroba-Lake Kopiago Open Electorate

\begin{tabular}{|c|c|}
\hline Candidate & Alliances and shared histories \\
\hline \multirow[t]{2}{*}{ Isaac Aruru Matiabe } & brother of the former MP Aruru Matiabe (1982-1992) \\
\hline & classmate of Ben Peri; the two were said to have an alliance \\
\hline Waa Alfred Akope & no known alliances with other candidates \\
\hline \multirow[t]{4}{*}{$\begin{array}{l}\text { Ronald Kendopa } \\
\text { Kulukua }\end{array}$} & $\begin{array}{l}\text { reputed to have been funded by Kekeno to split Peri's and Thomas's } \\
\text { votes }\end{array}$ \\
\hline & related to both Ben Peri and Petrus Thomas \\
\hline & encouraged supporters to give their preferences to Paiele Elo \\
\hline & publicly stated that he would work with Petrus Thomas, if he won \\
\hline McEnene Mai Elo & son of Paiele Elo, Member for Koroba-Lake Kopiago (1977-1982) \\
\hline \multirow[t]{3}{*}{ Matthew Magaye } & stood down in favour of Petrus Thomas in 2003 \\
\hline & $\begin{array}{l}\text { signed a memorandum of understanding with Ben Peri to exchange } \\
\text { preferences }\end{array}$ \\
\hline & $\begin{array}{l}\text { closely aligned with the former Southern Highlands Province } \\
\text { governor, Hami Yawari }\end{array}$ \\
\hline \multirow[t]{2}{*}{ John Kekeno Kelewa } & sitting member (2006-2007) \\
\hline & former secretary to and business associate of Herowa Agiwa \\
\hline \multirow[t]{3}{*}{ Mattias Olape } & Catholic Priest-appealed to Catholics for support \\
\hline & strongest polling Huli candidate in 2003 supplementary elections \\
\hline & no known alliances with other candidates \\
\hline
\end{tabular}

At least four minor 'vote-splitting' candidates were reported to be receiving financial support from the more serious candidates. ${ }^{10}$ Specifically, it was widely asserted that Agiru Hole was funded by Ben Peri to split John Kekeno's base vote, and that Paiele Elo, Ronald Kulakua and McEnene Mai Paiale Elo were all sponsored by and/or receiving support from John Kekeno to split Ben Peri's and Petrus Thomas's votes. Thomas Tupia was also considered a vote-splitter and was widely held to be working with Matthew Magaye to split the Kopiago vote, which was expected to go to Peri and Thomas. It was not clear whether Tupia was receiving financial support from Magaye.

In the lead-up to the election Matthew Magaye, who had contested the seat on four previous occasions, being runner-up in 1992 and 1997, was acknowledged to have strong support in Auwi-Logaiyu. He was the sole candidate from that LLG area. However, the 2006 by-election had shown that he lacked the ability to draw preferences from elsewhere in the electorate, and that his support was on the wane. Indeed in 1997, Magaye had gained 6582 votes, yet in the 2006 by-election he had picked up only 4449 first preference votes. Magaye sought to address his diminishing popularity by having Tupia stand to split the Kopiago vote and by seeking to capture preferences which might otherwise have flowed to the Kopiago candidates. He sought to achieve the latter by entering into a memorandum of understanding with Ben Peri to exchange preferences.

10 This strategy has been successfully employed in past elections in this electorate (see Haley 2002, 2004). 
Both strategies failed as only 18 of Tupia's 810 votes flowed to Magaye upon elimination (most flowed to Peri and Thomas) and Magaye himself was eliminated before Peri. ${ }^{11}$

Not all the weaker candidates were merely vote splitters - some were standing to increase their profile in the electorate. Paul Pora Wasdok, for instance, was reputed to be standing so people 'would know him in 2012' while Kulakua was contesting to improve his standing for the LLG elections. In his case this proved an effective strategy, as he was elected Lake Kopiago LLG president in 2008. Phillip Pakalu's reason for contesting was the most unusual. Evidently he was contesting because his wife, Lucy Pakalu, had contested the seat during the 2006 by-election, gaining 66 first preference votes, finishing 16th in a field of 20 candidates. Apparently she had challenged him to contest to demonstrate whether he could pull more votes than she had. Phillip who had previously contested the 1992 elections, gaining only a handful of votes, pulled only 47 first preference votes and finished 15 in a field of 17.

\section{Campaigning in 2007}

As expected, campaigning in the 2007 general election was generally accommodative, with candidates being able to campaign more widely and move around more freely than they had in either the 2002 national elections or the 2003 supplementary elections - something that had also been observed in previous LPV by-elections (Standish 2006:8; Haley 2006:24). That said, candidates did not move around as freely as they had in the 2006 by-election, and few campaigned across ethnic boundaries. Indeed, 2007 saw the return of ethnically closed campaigning (cf. Haley 2002; 2004; 2007), with Huli candidates campaigning in North Koroba and South Koroba - the Huli-speaking parts of the electorate - and Duna candidates campaigning at Kopiago and in AuwiLogaiyy - the predominantly Duna-speaking parts of the electorate. Petrus Thomas proved to be the only real exception to this in that he spent several weeks at a time in the electorate, campaigning in both Duna- and Huli-speaking areas (Figure 21.2). None of the Huli candidates campaigned at Kopiago this time around, although several, including Matthias Olape and Isaac Matiabe, had during the 2006 by-election.

\footnotetext{
11 In the 2006 by-election Ben Peri had in fact entered into an alliance with, and had reportedly provided financial support to, Auwi-Logaiyu candidate Geoffery Kara, in an effort to split Matthew Magaye's vote and that of Petrus Thomas. Thomas had picked up most of the Auwi-Logaiyu votes in 2003. The strategy was only partially successful in that only 147 of Kara's 575 votes flowed to Peri on elimination. Of the remaining votes 193 flowed to Thomas, 145 to Magaye and 51 were shared between a further seven candidates.
} 


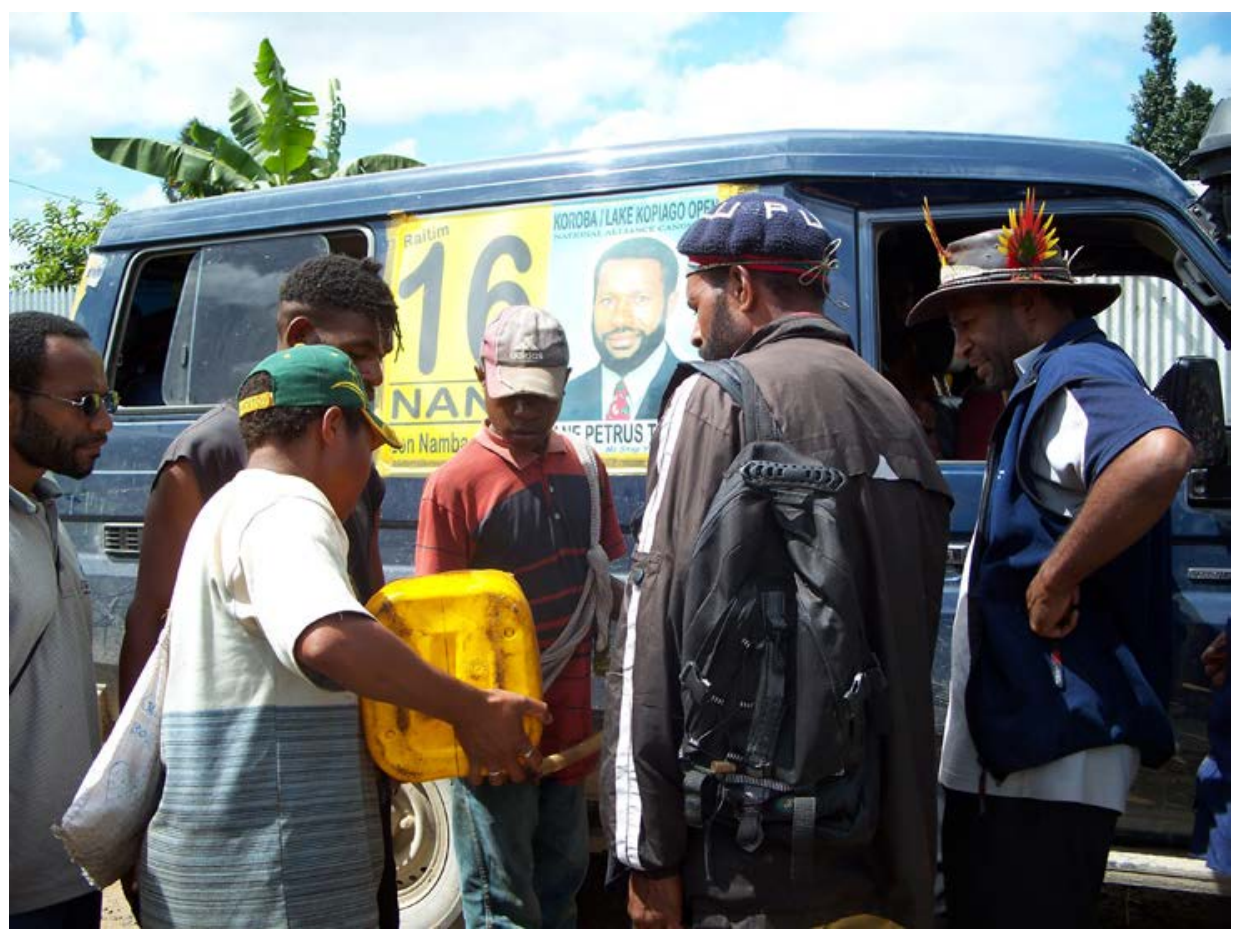

Figure 21.2: Petrus Thomas on the campaign trail in Tari, 23 June 2007

Compared with previous elections, including the 2006 by-election, campaigning was a much more low-key affair. Few of the candidates spent much time campaigning in the electorate, relying instead on campaign managers and diehard supporters to campaign on their behalf. Active campaigning by candidates was confined to the later stages of the campaign period. Generally, candidates were observed to concentrate their campaign efforts on areas where they believed they had base support, and on attending rallies and opening ceremonies in areas where preferences were deemed to be on offer (see chapter 20).

While it was evident from the way many of the not-so-strong candidates campaigned that they did not fully appreciate the importance of preferences, the top six candidates clearly did. All campaigned strategically, seeking first preferences in their home areas and minor preferences elsewhere, whereas the not so serious candidates campaigned mostly for minor preferences. Overall there was little concerted collaboration between candidates and no serious evidence of widespread preference swapping between parties or individual candidates, although compared with 2006 there was certainly more cooperation between candidates, which suggests a growing awareness about the way LPV works. For example, Ben Peri and Matthew Magaye entered into a memorandum of understanding to exchange preferences, while Paiele Elo and Ronald Kulaka were 
observed to encourage their supporters to preference each other. Importantly, these latter agreements also reflected the widespread view that preferences should be retained within the same cultural, linguistic or ethnic group.

It was also suggested that this was the reason John Kekeno provided support to three Duna candidates, in that he recognised that 'Duna' votes were unlikely to flow to him in the form of preferences but was keen to see them exhausted so as to prevent them from flowing to the two strong Duna candidates-Peri and Thomas. If this was indeed his strategy, it did not prove particularly effective, as candidates have little control over the way their supporters allocate preferences. For instance, when Paiele Elo Ronald Kulakua and McEnene Mai Elo were eliminated, half of their votes were distributed to other Duna candidates, particularly Thomas and Peri.

As in previous elections, candidates offered incentives of one kind or anothercash and promises of projects and future support - in order to secure votes. Several of the candidates gave out road maintenance and grass cutting contracts, while some funded or made arrangements for people living outside the electorate to travel home in order to cast their votes. Indeed in the days prior to polling there were constant streams of public motor vehicles, reputedly hired by Ben Peri, Petrus Thomas, John Kekeno and Herowa Agiwa, ferrying voters into the electorate. The stronger candidates also put considerable effort into inflating electoral rolls in areas where they enjoyed base support, and into influencing key electoral officials. Much effort was also put into attempts to have key electoral officials removed and replaced at the eleventh hour-a strategy successfully employed in past elections (see Haley 2004:20).

\section{Influence of political parties}

As has been noted by observers of previous Papua New Guinea elections, including the LPV by-elections conducted under the Organic Law on National and Local-Level Government Elections 2002, party endorsement, where it occurs, often means very little on the ground (Standish 2006:10; see also Haley 2004:18). Gibbs (2006:13), for example, notes that in the 2004 Wabag by-election, only two candidates had party endorsement and that party affiliation 'was not a very significant factor in voting patterns'. Standish et al. (2004:6) also note that party policies are seldom discussed and that party politics is 'largely decorative', being confined to 'impressive nomination rallies' and the occasional fleeting visit by party leaders or prominent ministers. Such statements ring true in the Koroba-Lake Kopiago context.

In the 2007 general election, 10 of the 17 candidates contesting the KorobaLake Kopiago Open seat had party endorsement. More particularly, the six top candidates - John Kekeno (People's Action Party), Father Mathias Olape 
(People's Party), Ben Peri (Pangu), Herowa Agiwa (PNG Country Party), Petrus Thomas (National Alliance) and Isaac Matiabe (New Generation Party) all had party endorsement.

In the Papua New Guinea context, though, party endorsement in one election does not signal long-term association with a particular party. Instead it is viewed as a temporary alliance entered into for the purpose of the election in order to gain funding and logistical support. For example, Petrus Thomas, the National Alliance endorsed candidate in 2007, had contested the 2006 by-election as a People's National Congress candidate, and was elected to parliament in 2003 after running as a People's Progress Party candidate. Herowa Agiwa, the former MP (1992-2002), has similarly shifted party affiliation several times. He had stood as a People's Democratic Movement candidate in 2002, a Pangu candidate in 2003, an independent in 2006, and was endorsed by the PNG Country Party in 2007. Likewise, Father Mathias Olape was endorsed by the People's Action Party in 2002, National Alliance in 2006 and the People's Party in 2007. Even Ben Peri, who had contested the last three elections under the United Resources Party banner, changed allegiance in 2007, this time running with Pangu.

As in earlier elections there was no evidence to suggest that party affiliation signalled an endorsement of particular political views or positions. Indeed all Koroba-Lake Kopiago candidates, party endorsed and independent alike, campaigned on similar platforms, asserting that they would be a good leader and would bring goods and services. Collectively they promised to support church, youth and women's groups; to bring development; to ensure roads and airstrips were maintained; and to ensure that schools and health services were properly staffed and funded.

Seemingly, party affiliation had little influence on voters. This is not to suggest that parties are completely irrelevant. To the contrary, strong candidates sought and were able to gain party endorsement, and those with party endorsement generally polled quite well. This is because parties seek to endorse likely winners, or those with a real chance of success. In the Koroba-Lake Kopiago context, party endorsement is viewed as part of the candidate's broader deportment, which itself is seen to reflect their inner worth and likelihood of success at the polls (see Haley 2008, 2004). For this reason, Phillip Pakalu's failure to gain party endorsement from Star Alliance gave rise to much discussion in the electorate and was seen to signal that his campaign was doomed to fail.

In the final analysis, six of the ten party-endorsed candidates were the toppolling candidates at the end of the first preference count and the final six candidates in the race. This, I suggest, had more to do with the overall popularity of those candidates than their party affiliations as such. Where candidates had 
party endorsement, this typically translated into some level of support with campaign expenses - such as candidate posters and voter cards, and in some cases vehicle hire.

\section{Influence of guns}

Guns did not feature in this election to anywhere near the extent they had in 1997 and 2002. They were, however, still out there. In fact, members of the observer team saw firearms during nominations, the campaign period, in the lead-up to the poll, and even on polling day, but these and other weapons such as bush knives tended not to be openly displayed at polling places (except at Kopiago - see below), or used to influence the vote, as they had been in the past. It should be noted, though, that weapons were close to hand at several polling places, having been hidden in the nearby bush should they be needed.

At Koroba, where there was a strong security presence - notably armed PNGDF personnel (see chapter 8)-no weapons were seen at polling places, although several observers reported seeing candidates and supporters brandishing homemade weapons during the campaign period. Several high-powered weapons including AR15s, M16s and an Ultimax 100 were also seen (see chapter 8). At Kopiago, however, where the security forces were unarmed, several observers reported the presence of guns, bush knives and axes at polling places. Not surprisingly these observers felt that the security situation was similar to that of the failed 2002 elections. The majority, however, felt that the security situation was significantly better, attributing this to the PNGDF presence.

\section{Influence of 'money politics'}

While guns played less of a role in this election, 'money politics' was more significant than ever. Several candidates spent huge amounts of money offering material incentives to voters, and two were rumoured to have spent as much as K2 million on their respective campaigns. Voters in Koroba-Lake Kopiago electorate capitalized on the huge amount of money available by courting multiple candidates and promising support in return for modest cash payments of up to K100. They also erected grandstands and conducted opening ceremonies as a means of generating money (see chapter 20). These rallies/opening ceremonies were organized by clans, church congregations, youth and women's groups and school committees as a means of generating funds. Candidates were invited to speak at these events and were expected to pay for the privilege. Observers reported that hire rates ranged between $\mathrm{K} 100$ and several thousand kina per speaking engagement. One rally at Guala, a week prior to the polls, netted K24,500 for the local Christian Brethren Church (CBC) community. Of this the sitting MP, John Kekeno, 'donated' K7000 to the CBC community school, K9000 
to the CBC headquarters, K3000 to the CBC youth and K2000 to the CBC women's group. Seven candidates attended and spoke at this rally. A separate rally had been organized by the Guala youth a fortnight prior to this rally. It was attended by four candidates.

Observers also witnessed candidates and their supporters actually bribing or attempting to bribe voters with cash on polling day, and two observers witnessed vote-buying-related fights at polling stations. At Kakarene 1, a fight was observed to have erupted after a voter accepted payment from two separate candidates, while at Gunu 1 a fight erupted after a young man accepted money from a campaign manager then gave his first vote to a different candidate. At the same polling station a campaign manager seeking to gain votes for the sitting MP was seen to be promising blankets, stereos and spades in return for a first preference vote.

Somewhat ironically, several candidates also complained to the observer team about the inflationary aspect of elections, saying that the large amounts of cash being splashed around would inflate people's expectations in coming elections. Indeed it is evident that candidates are now having to rely on larger and larger networks in order to finance their campaigns, and that wealthy individuals (businessmen and community leaders) are financing and/or contributing towards candidates' campaigns in order to create indebtedness and to ensure that the candidate is beholden to them should they win.

\section{Polling}

Since 1997 voter turnout in Koroba-Lake Kopiago has always been high, with votes cast being significantly higher than the number of eligible citizens (see Table 21.1), something facilitated by the poor state of the electoral roll. In this respect the 2007 election was no different from earlier elections. As noted earlier in this chapter, the 2007 Koroba-Lake Kopiago electoral roll, which was heavily inflated, contained 48,739 names. At the close of polling some 45,020 votes had been cast, and of these 44,473 were determined to be allowable ballots. This represents around 17,000 more votes than there are eligible citizens in the electorate.

Polling in the 2007 elections was far more peaceful than in recent elections, due in no small part to the huge security presence (see chapter 8). It remained generally chaotic, however, and was marred by widespread irregularities. Examples of election fraud and malpractice emerging out of the 2007 elections are both plentiful and diverse and demonstrate continuities with voter and candidate behaviour in the 1997 and 2002/2003 elections. 
Under-age voting (very small children, even babies, were seen voting or having votes cast on their behalf), multiple voting, 'line-up' voting, serial voting (that is, voting at different polling stations), 'outside' voting (voters from neighbouring electorates) and proxy voting were all commonplace. Almost without exception, voting took place publicly and there was no secret ballot. The indelible ink was not used or was used randomly, and excess ballot papers were used in many cases. Assisted voting, much of it seemingly forced, was commonplace (Figure 21.3) and at several polling stations polling officials were observed to be issuing pre-marked ballot papers. In most cases, the electoral roll was not used properly, if at all, and at some polling stations (such as Tumbite, Pumbulumu 1 and Pumbulumu 2) groups of young men were issued with entire books of ballot papers, which were completed en masse.

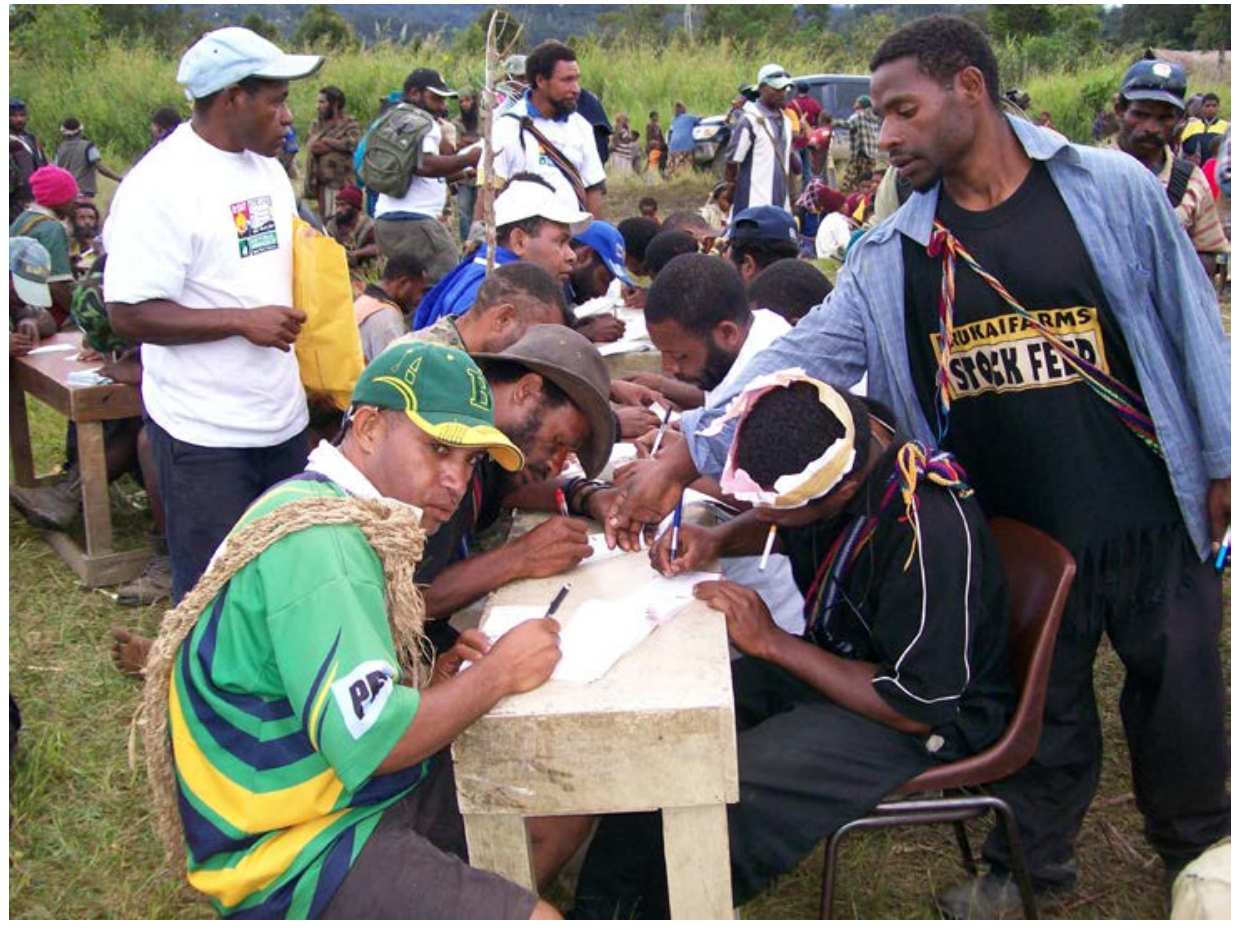

Figure 21.3: Assisted voting at Koroba, 30 June 2007

More than half $(50 / 82)^{12}$ of all polling stations were set up within easy walking distance of another (less than 500 metres apart) and many were set up literally side by side. At Lake Kopiago, for instance, the Kopiago Station and Ayukuni (Alukuni) polling stations were about 500 metres from each other and people were

12 In addition to the 36 wards which have paired names (such as Teria 1 and 2, Andiria 1 and 2, Hedemari 1 and 2 etc.) there were an additional 14 wards which were paired on polling day, namely Mbuli and Maria, Kopiago Station and Aiyuguni, Ayenda and Kagoma, Hauwinda and Kudiebi, Kenamu and Walukumu, Pandu and Koroba Station, and Tumbite and Tangimapu. 
observed walking back and forth voting at each of them, sometimes many times. More extreme examples included four polling stations (Tumbite, Pubulumu 1, Pubulumu 2 and Tangimapu) being set up side by side on Tumbite airstrip at Pureni, and seven polling stations being set up on Koroba Government Station (Teria 1, Teria 2, Pandu, Andiria 1, Andiria 2, Koroba Station and Kereneiba Part 2). These seven polling stations were set up within metres of each other, and voters were observed moving backwards and forwards between them (Figure 21.4). Voters were similarly observed to move between Maria and Mbuli polling stations. There a relatively small number of people (approximately 300 voters) managed to cast 2204 votes, of which 2082 went to a single candidate, Isaac Matiabe, while at Tumbite an amazing 5941 votes were cast with 5813 of them going to Father Mathias Olape.

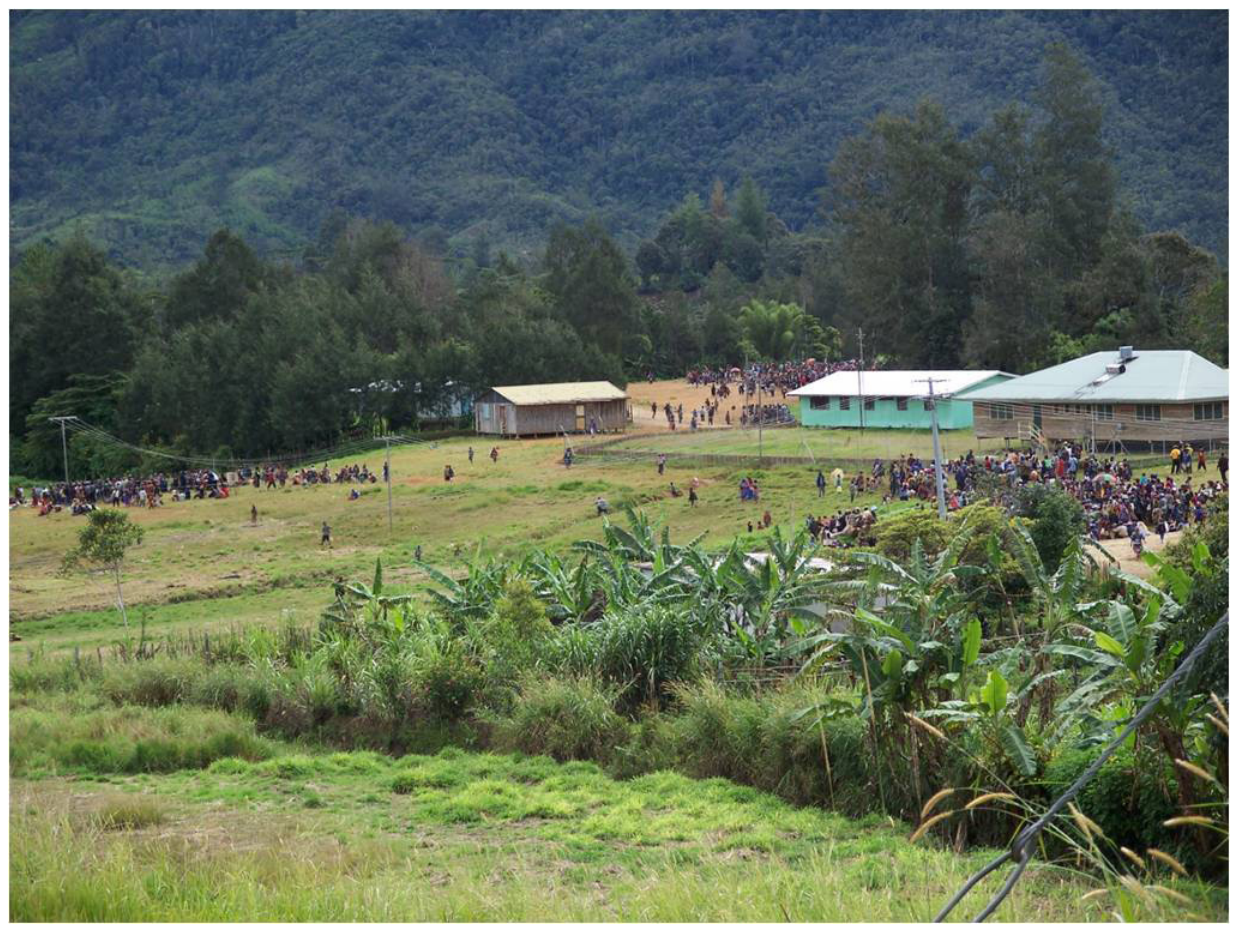

\section{Figure 21.4: Seven polling stations in close proximity at Koroba Station}

Despite the many irregularities, there is also considerable evidence that people at the majority of polling places actually got to vote. Indeed men, women and children alike were observed to be lined up, in a reasonably orderly fashion, waiting for the opportunity to vote, and few reported being denied a vote. In fact many who wanted to were afforded the opportunity to vote several times. At Wurukumu, for instance, voters lined up, gave their names and then proceeded to the voting compartment where whole books of ballot papers were located. 
There they were permitted to fill out as many ballot papers as they liked, until the papers ran out. At this particular polling place all 562 votes went to the sitting MP, John Kekeno.

In a post-polling survey of 200 voters (100 men and 100 women) at different locations throughout the electorate, 46 men and 12 women admitted to having voted more than once. Observations made on polling day suggest that the proportion of voters voting more than once was significantly higher. As part of the same post-polling survey 32 men and 34 women (one-third of all respondents) reported having experienced intimidation while voting, while 20 men and 29 women (one-quarter of all respondents) felt that the 2007 election was worse than the failed elections of 2002.

In spite of the intimidation experienced by a significant number of voters, the spread of votes at individual polling places suggests that a good number of voters were permitted to exercise choice when voting. At 25 of the 80 polling places ( 31 percent) the candidate that secured the most votes gained less than 50 percent of the votes cast, and at a further nine polling places ( 11 percent) the top-polling candidate gained between 51 and 60 percent of the vote. At these polling places votes were typically shared between several candidates, suggesting voters were afforded genuine choice when casting their votes. That said, there were also 15 polling places (19 percent) at which the top-polling candidate gained more than 96 percent of the votes cast, and a further eight polling places (10 percent) where the top-polling candidate gained 91-95 percent of the votes cast. In some cases (for instance Hirane, Aiyukuni, Kakoma and Walukumu) this can be explained in terms of a base vote and we can assume a fair degree of community consensus (although I doubt total consensus), but in others (such as Tumbite, Pumbulumu 1, Pumbulumu 2 and Tobi) it represents a forced, coerced or controlled vote. At places such as Tumbite and Pumbulumu where the vote was forced, individuals were denied the opportunity to mark their own papers. Not surprisingly the places where block votes and controlled votes were registered were all heavily over-enrolled and in fact tended to coincide with the wards that were most over-enrolled (see Tables 21.4 and 21.5).

Table 21.9 compares the top-polling candidates' shares of the votes by ballot box in 2003, 2006 and 2007. It reveals a significant increase in bloc voting and a decrease in the number of polling places where votes were genuinely shared between candidates. Specifically, Table 21.9 shows a three-fold increase in the number of boxes in which the top-polling candidate gained more that 90 percent of the votes cast and an almost four-fold increase in boxes where the leading candidate gained between 96 and 100 percent of the votes cast. 
Table 21.9: Comparison of leading candidates' share of the vote in 2003, 2006 and 2007, by ballot box

\begin{tabular}{lrrrrrr}
\hline $\begin{array}{l}\text { Leading candidates' } \\
\text { share of the vote } \\
\text { (percent) }\end{array}$ & Number & Percent & Number & Percent & Number & Percent \\
\hline $96-100$ & 4 & 5.0 & 7 & 8.5 & 15 & 19.0 \\
$91-95$ & 3 & 4.0 & 7 & 8.5 & 8 & 10.0 \\
$81-90$ & 6 & 7.5 & 7 & 8.5 & 6 & 8.0 \\
$71-80$ & 2 & 2.5 & 7 & 8.5 & 9 & 11.0 \\
$61-70$ & 14 & 17.5 & 8 & 10.0 & 8 & 10.0 \\
$51-60$ & 21 & 26.0 & 11 & 13.0 & 9 & 11.0 \\
$<50$ & 30 & 37.5 & 35 & 43.0 & 25 & 31.0 \\
\hline
\end{tabular}

That voters were afforded real choice at many polling stations can be demonstrated by comparing the way votes were allocated at Koroba Station (Table 21.10) and within Kopiago Basin (Table 21.11). Table 21.10 shows that the votes cast at the seven Koroba Station polling places were shared between six main candidates.

Table 21.10: Summary of polling at the seven Koroba Station polling places, 2007

\begin{tabular}{lrrrrrrr}
\hline Candidate & Teria 1 & Teria 2 & Pandu & Andiria 1 & Andiria 2 & $\begin{array}{r}\text { Koroba } \\
\text { Station }\end{array}$ & $\begin{array}{r}\text { Kereneiba } \\
\text { Part 2 }\end{array}$ \\
\hline Ben Peri & 13 & 24 & 16 & 12 & 2 & 11 & 14 \\
John Kekeno & 142 & 75 & 116 & 131 & 33 & 67 & 19 \\
Mathias Olape & 6 & 46 & 74 & 46 & 3 & 64 & 1 \\
Herowa Agiwa & 66 & 214 & 89 & 66 & 4 & 51 & 336 \\
Isaac Matiabe & 2 & 29 & 182 & 27 & 15 & 28 & 2 \\
Waa Akope & 220 & 34 & 90 & 157 & 458 & 11 & 1 \\
Others & 2 & 4 & 5 & 9 & 3 & 5 & 2 \\
Total & 451 & 435 & 417 & 457 & 518 & 237 & 375 \\
\hline
\end{tabular}

Table 21.11: Summary of polling at the eight Kopiago Basin polling places, 2007

\begin{tabular}{|c|c|c|c|c|c|c|c|c|}
\hline Candidate & Hirane & Aiyukuni & $\begin{array}{r}\text { Kopiago } \\
\text { Station }\end{array}$ & Suwaka & Dolowa & $\begin{array}{r}\text { Wagia/ } \\
\text { Pongolaia }\end{array}$ & $\begin{array}{c}\text { Peragoia/ } \\
\text { Mbatane }\end{array}$ & Dilini \\
\hline Ben Peri & 844 & 2 & 115 & 446 & 407 & 0 & 55 & 116 \\
\hline $\begin{array}{l}\text { Petrus } \\
\text { Thomas }\end{array}$ & 0 & 634 & 95 & 60 & 71 & 526 & 40 & 22 \\
\hline $\begin{array}{l}\text { Thomas } \\
\text { Tupia }\end{array}$ & 0 & 1 & 161 & 63 & 19 & 0 & 24 & 1 \\
\hline $\begin{array}{l}\text { Ronald } \\
\text { Kulakua }\end{array}$ & 0 & 0 & 1 & 0 & 0 & 0 & 1 & 0 \\
\hline $\begin{array}{l}\text { John } \\
\text { Kekeno }\end{array}$ & 0 & 75 & 16 & 35 & 1 & 7 & 18 & 4 \\
\hline Others & 0 & 4 & 15 & 34 & 22 & 2 & 0 & 26 \\
\hline Total & 844 & 637 & 403 & 638 & 520 & 535 & 138 & 169 \\
\hline
\end{tabular}




\section{The results}

The official election results are shown in Table 21.16 in the appendix to this chapter. They reveal that the incumbent, John Kekeno, was returned, having gained 18 percent of first preference votes and 37 percent of the allowable ballot. By comparison, he had gained only 12 percent of first preference votes and 30 percent of the allowable ballot in the 2006 Koroba-Lake Kopiago by-election (see Table 21.14 in the appendix to this chapter). Despite the gain in popularity, Kekeno still received a smaller overall percentage of the vote than Petrus Thomas did in 2003, the last election to be conducted under the first-past-thepost system. Indeed in 2003 Thomas, who was one of only two Duna candidates running against 10 Huli candidates, gained 39 percent of the allowable ballot $(16,401$ of the 42,595 votes cast).

This is particularly noteworthy as it had been expected that with the introduction of LPV, the 2007 election would be more peaceful and see the election of MPs with wider and more representative mandates (Standish 2006:197; Reilly 2006:189; PNGEC 1997:13). It was also suggested that LPV would reduce the number of candidates contesting elections and improve the chances of women being elected. The later proved unfounded in that men in Koroba-Lake Kopiago continued to assert their rights over those of women, insisting that women remain their property and should therefore vote in accordance with their husband's wishes.

Generally speaking, LPV has delivered larger mandates (see Anere and Wheen 2009:22-26). Nearly two-thirds of the parliamentarians elected to the national parliament in 2002 received less than 20 percent of the vote under the first-pastthe-post system. The 2002 election also saw the mean percentage of the vote required to win a seat down from 18 percent in 1997 to only 16 percent (Reilly 2006:189). Yet in 2007, under LPV, only 16 MPs (15 percent) were elected with less than 20 percent of the vote (Anere and Wheen 2009:23).

Under LPV the average overall mandate typically doubled, with winning candidates receiving 35-36 percent of the total allowable ballot after the distribution of preferences (see Haley and Anere 2009:60; Anere and Wheen 2009). ${ }^{13}$ In this respect, the Koroba-Lake Kopiago results are consistent with those elsewhere around the country. However, the Koroba-Lake Kopiago case also demonstrates that the total number of candidates and where they are from plays a key role in determining the winning candidate's overall mandate, as evident from the 2003 results.

13 The mandates for provincial seats were typically higher than those for open seats. Indeed, successful candidates in provincial seats gained on average 41 percent of the allowable ballot, while successful candidates in open seats gained only 30 percent of allowable ballots. 
It is arguably still too early to judge whether LPV will deliver larger mandates and more broadly supported candidates in the longer term, for this will largely depend upon two things: first, whether LPV attracts fewer candidates or gives rise to a proliferation of candidates, and, secondly, whether voters choose to make their votes count.

The early indications from Koroba-Lake Kopiago are mixed. For instance, the 2006 by-election, conducted under LPV, attracted the largest field ever, and the 2007 general election saw a record number of Duna candidates contest the seat. It also saw a return to ethnically closed campaigning, and this contributed in part to the proliferation of Duna candidates, in that John Kekeno (who is ethnically Huli) sponsored and gave support to three Duna candidates in order to split the vote of the two very strong Duna candidates and in an attempt to exhaust a significant proportion of Duna votes. Given that this strategy proved somewhat successful, it may well be adopted by other candidates in future elections, thereby contributing to candidate proliferation.

What the Koroba-Lake Kopiago results do reveal is that a significant proportion of voters chose to make their votes count, by using their preferences far more strategically and effectively than they had in the 2006 by-election. In 2007, 68 percent of the formal votes remained live at the completion of the final count, while 85 percent were still live immediately prior to the final exclusion. This shows that voters allocated their preferences to strong candidates with a likelihood of success, rather than to minor local candidates. By contrast, the 2006 by-election had seen 44 percent of votes exhausted. On average, in 2007, across all 105 electorates for which there are election results, 40 percent of votes were exhausted (Anere and Wheen 2009:23). That a smaller proportion of votes was exhausted in Koroba-Lake Kopiago in 2007 will have contributed to the larger mandates witnessed by both the winning candidate and the runner-up, as compared with the 2006 by-election.

The Koroba-Lake Kopiago results also reveal that candidates have little control over the way their supporters allocate preferences. In short, preference deals did not work. Indeed, although Ben Peri and Matthew Magaye entered into a memorandum of understanding to exchange preferences, only 166 of the 1252 votes Magaye gained flowed to Peri on Magaye's elimination. By contrast, 461 flowed across the ethnic divide to the sitting MP John Kekeno, while 408 flowed to Peri's key rival Petrus Thomas. Similarly, only 18 of Thomas Tupia's 810 votes flowed to Matthew Magaye upon elimination. Instead the vast majority went to Petrus Thomas (288) and Ben Peri (279) and a good number (140) to John Kekeno.

In both of these cases some votes initially captured by a Duna candidate flowed to a Huli candidate. Despite the widespread rhetoric that preferences should 
be retained within the same cultural, ethnic or linguistic group, a significant proportion of votes flowed across the ethnic divide with each and every elimination (Table 21.12). Overall, some 44 percent of the Duna votes distributed as the first nine Duna candidates were eliminated flowed to Huli candidates. This suggests that for a significant proportion of voters enmities between rival candidates within the same ethnic group or the pulling power of money proved stronger than calls for ethnic unity.

Either way, strong candidates (Huli and Duna alike) managed to gain a spread of votes and preferences across the electorate (cf. May 2006:118). John Kekeno, the winning candidate, picked up votes in 73 of 80 ballot boxes, and was the toppolling candidate at 19 polling places and the second-highest polling candidate at 19 others. Peri and Thomas, the top-polling Duna candidates both picked up votes in more than three-quarters of all boxes - 61 boxes in Peri's case and 66 boxes in Thomas's case. This is particularly noteworthy as only 26 of the 80 wards are Duna speaking. These results are consistent with the 2006 byelection results, where Kekeno picked up votes in 74 boxes, while Peri and Thomas picked up votes in 72 and 65 boxes respectively.

Table 21.12: Flow of preferences with each elimination

\begin{tabular}{|c|c|c|c|c|c|c|c|}
\hline No. & Candidate & Ethnicity & $\begin{array}{r}\text { Total } \\
\text { votes } \\
\text { received }\end{array}$ & $\begin{array}{r}\text { Votes } \\
\text { to Huli } \\
\text { candidate }\end{array}$ & $\begin{array}{r}\text { Votes } \\
\text { to Duna } \\
\text { candidate }\end{array}$ & $\begin{array}{r}\text { Votes } \\
\text { exhausted }\end{array}$ & $\begin{array}{r}\text { Votes } \\
\text { to other } \\
\text { ethnic } \\
\text { group } \\
(\%)\end{array}$ \\
\hline 19 & Paiyale Elo & Duna & 10 & 3 & 7 & 0 & 30 \\
\hline 22 & Ronald K. Kulakua & Duna & 46 & 21 & 25 & 0 & 46 \\
\hline 11 & $\begin{array}{l}\text { Dokta Philip } \\
\text { Pakalu }\end{array}$ & Duna & 48 & 16 & 31 & 1 & 34 \\
\hline 14 & Agiru Hole & Huli & 130 & 98 & 32 & 0 & 25 \\
\hline 23 & McNene Mai Elo & Duna & 142 & 76 & 65 & 1 & 54 \\
\hline 10 & Paul Pora Wasdok & Huli & 663 & 454 & 208 & 1 & 31 \\
\hline 12 & Thomas Tupia Ape & Duna & 810 & 211 & 594 & 5 & 26 \\
\hline 15 & Allan Mone & Duna & 1,097 & 289 & 801 & 7 & 27 \\
\hline 21 & Waa Alfred Akope & Huli & 1,168 & 1,056 & 110 & 2 & 9 \\
\hline 24 & Matthew Magaye & Duna & 1,252 & 732 & 474 & 46 & 61 \\
\hline 17 & Daniel Mapiria & Huli & 3,086 & 2,499 & 493 & 94 & 16 \\
\hline 20 & Isaac Matiabe & Huli & 5,776 & 3,348 & 1,363 & 1,065 & 29 \\
\hline 16 & Petrus Thomas & Duna & 6,642 & 2,093 & 2,332 & 2,217 & 47 \\
\hline 13 & Herowa Agiwa & Huli & 8,215 & 3,939 & 845 & 3,431 & 18 \\
\hline 18 & Ben Epe Peri & Duna & 10,619 & 3,082 & 0 & 7,537 & 100 \\
\hline
\end{tabular}


The garnering of broad-based support cannot, in the Koroba-Lake Kopiago case, be attributed to LPV. Indeed it predates the switch to preferential voting. In 2003 the winning candidate, Petrus Thomas, gained votes from 64 polling places. He polled particularly well at half of all polling stations, ranking first in respect of 23 ballot boxes and second in respect of a further 17 ballot boxes. The runner-up, Ben Peri, had arguably even broader support, picking up votes in all but four ballot boxes. He gained the largest or second largest vote in just over half the ballot boxes (43/80) - being the top-polling candidate at 16 polling places and second-highest ranked candidate at a further 27 polling places.

\section{Conclusion}

In 2007, fraud, malpractice and money triumphed yet again in the Koroba-Lake Kopiago Open electorate. As a consequence, the election results lack integrity. Had the election been the least bit fair, the outcome would most likely have been very different. Certainly there would have been far fewer votes. It is worth noting, too, that during the 2003 supplementary elections the total number of votes cast in North Koroba and South Koroba was 16,385. This was because there was a huge security presence, and because the security forces did not allow multiple and under-age voting. Based on projections from the 1990 census the expected enrolment for these two LLG areas at that time was 16,280. In 2007, the expected enrolments for North Koroba and South Koroba were 18,110, yet 30,288 votes were cast. These additional votes were surely enough to have changed the order in which candidates were eliminated, which in turn would have changed the flow of preferences and most likely the overall outcome.

Two key factors contributed to and facilitated the cheating and malpractice (under-age voting, double and multiple voting, serial voting and outside voting) observed on polling day. The first was the poor state of the new electoral roll, which included children, dead people, and people from neighbouring electorates (particularly the Tari electorate), as well as thousands of duplicates, and the second was the location and positioning of polling stations. As noted above, polling places were often set up side by side to facilitate voter movement between polling stations.

It is also worth noting that LPV affected the results in only one-fifth of all electorates (Anere and Wheen 2009:27), and that, in 80 percent of cases, the candidate who led at the end of the first preference count went on to win the seat. In other words, preferences affected few outcomes. And yet in terms of electoral administration, LPV is more certainly costly and more difficult to administer. Overall the introduction of LPV has required a lot of effort and expense for very little gain, and it may be that in the longer term the negative consequences, such as the proliferation of money politics, will far outweigh any benefits. 
In the meantime, it is evident that the PNGEC was willing to turn a blind eye to the rampant fraud and malpractice witnessed in Koroba-Lake Kopiago Open electorate in 2007. Indeed there was a clear resolve, which came direct from the prime minister himself, to avoid a repetition of the events of 2002, and as a consequence the elections in Southern Highlands Province drew little scrutiny. Seemingly there was a willingness to accept the election results 'no matter what transpired'; this is the legacy of 2002. It is hoped that the electoral environment in 2012 will make for more honest assessments of future elections and that the PNGEC will not be scared to fail elections that should clearly be deemed to have failed. With development of the liquefied natural gas project well under way, the stakes are much higher than ever before and this only serves to further fuel the win-at-all-costs mentality the has emerged over the last decade or so.

\section{References}

Anere, R. and Wheen, K., 2009. Priorities for a Free and Fair Election: An NRI Issues Analysis. Discussion Paper No. 107. Port Moresby: The National Research Institute.

Gibbs, P., 2006. 'Limited preferential voting and Enga political culture', Catalyst 36(1):3-25.

Haley, N., 2002. 'Election fraud on a grand scale: the case of the Koroba-Kopiago Open electorate', in R. J. May and R. Anere (eds), Maintaining Democracy: The 1997 Elections in Papua New Guinea. Port Moresby: Department of Political Science, University of Papua New Guinea, pp. 123-139.

Haley, N., 2004. 'A failed election: the case of the Koroba-Lake Kopiago Open electorate', in P. Gibbs, N. Haley and A. McLeod, Politicking and Voting in the Highlands: The 2002 Papua New Guinea National Elections, SSGM Discussion Paper 2004/1. Canberra: State, Society and Governance in Melanesia Project, The Australian National University, pp. 16-26.

Haley, N., 2007. 'Cosmology, morality and resource development: election outcomes and moves to establish a separate Hela Province', in N. Haley and R. J. May (eds), Conflict and Resource Development in the Southern Highlands of Papua New Guinea. Canberra: ANU E Press, pp. 57-68.

Haley, N., 2008. 'When there's no accessing basic health care: local politics and responses to HIV/AIDS at Lake Kopiago, Papua New Guinea', in L. Butt and R. Eves (eds), Making Sense of AIDS: Culture, Sexuality and Power in Melanesia. Honolulu: University of Hawaii Press, pp. 24-40. 
Haley, N. and Robinson, R., 1998. 'Bogaia, Yeru and Duna Census: Mbulago to Galaga'. Report prepared for the Porgera Joint Venture.

Haley, N., Moya, P., Randa, B., Alo, R., Kendoli, K., Ferguson, S. and Standish, B., 2006. 'Koroba-Lake Kopiago By-Election Observation Final Report'. Report Prepared for the Electoral Support Program Phase 2.

Haley, N. and Muggah, R., 2006. 'Jumping the gun: armed violence in Papua New Guinea', in Small Arms Survey 2006: Unfinished Business. Oxford: Oxford University Press, pp. 164-187.

Haley, N. and Anere, R., 2009. The 2007 Papua New Guinea National General Elections: Domestic Observation Report. Special Publication No. 52. Port Moresby: The National Research Institute.

May, R. J., 2006. 'The "clan vote" in Papua New Guinea open electorates: data from Angoram', Journal of Pacific Studies 29(1):108-129.

PNGEC (Papua New Guinea Electoral Commission), 1997. Report to the Sixth Parliament on the 1997 National Election by the Electoral Commissioner, $\mathrm{Mr}$ Reuben T. Kaiulo. July 1997. Port Moresby.

Reilly, B., 2006. 'Political reform in Papua New Guinea: testing the evidence', Pacific Economic Bulletin 21(1):187-194.

Robinson, R. P., 2002. 'Koroba-Kopiago Open: the final election', in R. J. May and R. Anere (eds), Maintaining Democracy: The 1997 Elections in Papua New Guinea. Port Moresby: Department of Political Science, University of Papua New Guinea, pp. 141-148.

Robinson, R. and Haley, N., 1998a, 'Hewa Census: Ambi to Papaki'. Report prepared for the Porgera Joint Venture.

Robinson, R. and Haley, N., 1998b, 'Hewa Census: Iyali to Eyaka'. Report prepared for the Porgera Joint Venture.

Somare, M., 2006. 'Statement by the Rt. Hon. Prime Minister on the law and order and general security situation in the Southern Highlands Province'. Statement to Parliament, 1 August 2006.

Standish, B., 2006. 'Limited preferential voting in Papua New Guinea: some early lessons', Pacific Economic Bulletin 21(1):195-211.

Standish, B., Gedare, D., Ketan, J. and Webster, T., 2004. 'Aide Memoire: Limited Preferential Voting: First Interim Report on the Highlands By-elections, May-June 2004'. 


\section{Appendix}

Table 21.13: Example of duplicate entries on the Tumbite ward roll

\begin{tabular}{|c|c|c|c|c|c|}
\hline Elector ID & Last name & First name & Sex & $\begin{array}{l}\text { Birth date } \\
\text { on roll }\end{array}$ & Occupation \\
\hline 76056181 & Abraham & Aluyas & $M$ & 1966 & Subsistence farmer \\
\hline 76008551 & Abarama & Aluya & M & 1987 & Student \\
\hline 76056508 & Abuhaya & Ege & $M$ & 1964 & Subsistence farmer \\
\hline 76008323 & Abuhaya & Ege & M & 1959 & Subsistence farmer \\
\hline 76056535 & Abuhaya & Albert & $M$ & 1970 & Subsistence farmer \\
\hline 76056538 & Abuhaya & Hebert & $M$ & 1968 & Subsistence farmer \\
\hline 76056513 & Abuhaya & Abraham & M & 1972 & Subsistence farmer \\
\hline 76008506 & Abuhaya & Abarama & $M$ & 1966 & Pastor \\
\hline 76056525 & Abuhaya & Joseph & M & 1983 & Student \\
\hline 76008642 & Abuhaya & Joseph & $M$ & 1966 & Subsistence farmer \\
\hline 76056523 & Abuhaya & Issac & M & 1984 & Student \\
\hline 76008600 & Abuhaya & Asiac & M & 1964 & Subsistence farmer \\
\hline 76056511 & Abuhaya & Manabule & $M$ & 1950 & Self employed \\
\hline 76008349 & Abuhaya & Manabule & M & 1966 & Worker \\
\hline 76008307 & Agobe & Timbame & $\mathrm{F}$ & 1962 & Household duties \\
\hline 76056345 & Agobe & Timbame & $\mathrm{F}$ & 1958 & Household duties \\
\hline 76008414 & Agobe & Wagili & $\mathrm{F}$ & 1967 & Household duties \\
\hline 76056386 & Agobe & Wagili & $\mathrm{F}$ & 1962 & Household duties \\
\hline 76006858 & Agobe & Wayama & $\mathrm{F}$ & 1980 & Household duties \\
\hline 76056294 & Agobe & Wayama & $\mathrm{F}$ & 1964 & Household duties \\
\hline 76008324 & Akobe & Helen & $\mathrm{F}$ & 1967 & Household duties \\
\hline 76056347 & Agobe & Helen & $\mathrm{F}$ & 1952 & Household duties \\
\hline 76008400 & Akobe & Anna & $\mathrm{F}$ & 1967 & Household duties \\
\hline 76056355 & Agope & Anna & $\mathrm{F}$ & 1973 & Household duties \\
\hline 76007865 & Akope & Mekeme & $\mathrm{F}$ & 1972 & Household duties \\
\hline 76056290 & Akobe & Mekeme & $\mathrm{F}$ & 1965 & Household duties \\
\hline 76007855 & Akope & Warali & $\mathrm{F}$ & 1974 & Household duties \\
\hline 76056292 & Akobe & Warali & $\mathrm{F}$ & 1974 & Household duties \\
\hline 76056690 & Alembo & Mbatai & $\mathrm{F}$ & 1952 & Household duties \\
\hline 76009491 & Alembo & Mbatai & $\mathrm{F}$ & 1948 & Household duties \\
\hline 76010727 & Alembo & Makondo & $M$ & 1956 & Magistrate \\
\hline 76056487 & Alembo & Makondo & M & 1952 & Committee member \\
\hline 76009577 & Alembo & Yakapi & $\mathrm{F}$ & 1980 & Household duties \\
\hline 76056700 & Alembo & Yakabi & $\mathrm{F}$ & 1967 & Household duties \\
\hline
\end{tabular}


Table 21.14: Koroba-Lake Kopiago Open electorate results, 2006 byelection

\begin{tabular}{|c|c|c|c|c|c|c|c|c|c|}
\hline No. & Candidate name & Party $^{a}$ & $\begin{array}{l}\text { First } \\
\text { prefs }\end{array}$ & $\begin{array}{r}\text { First } \\
\text { pref. } \\
\%\end{array}$ & $\begin{array}{r}\text { Final } \\
\text { total at } \\
\text { elim'n }\end{array}$ & $\begin{array}{c}\text { Prefs } \\
\% \text { of } \\
\text { final } \\
\text { total }\end{array}$ & $\begin{array}{l}\text { Final } \\
\text { total }\end{array}$ & $\begin{array}{r}\text { Final } \\
\%\end{array}$ & $\begin{array}{r}\% \text { of } \\
\text { allow. } \\
\text { votes }\end{array}$ \\
\hline 3 & $\begin{array}{l}\text { John Kekeno } \\
\text { Kelewa }\end{array}$ & PAP & 4702 & 11.5 & & 62.0 & 12,388 & 54.1 & 30.3 \\
\hline 1 & Ben Epe Peri & URP & 5978 & 14.6 & & 43.2 & 10,525 & 45.9 & 25.8 \\
\hline 7 & $\begin{array}{l}\text { Nane Petrus } \\
\text { Thomas }\end{array}$ & PNC & 5226 & 12.8 & 8423 & 38.0 & Excl 18 & 0 & 20.6 \\
\hline 8 & Mathias Olape & NA & 4497 & 11.0 & 7992 & 43.7 & Excl 17 & 0 & 19.6 \\
\hline 12 & $\begin{array}{l}\text { Issaac Aruru } \\
\text { Matiabew }\end{array}$ & Ind. & 3764 & 9.2 & 6290 & 40.2 & Excl 16 & 0 & 15.4 \\
\hline 13 & Mathew Magaye & Ind. & 4449 & 10.9 & 5485 & 18.9 & Excl 15 & 0 & 13.4 \\
\hline 9 & Herowa Agiwa & Ind. & 3238 & 7.9 & 4740 & 31.7 & Excl 14 & 0 & 11.6 \\
\hline 6 & Daniel Mapiria & Ind. & 2880 & 7.1 & 3453 & 16.6 & Excl 13 & 0 & 8.5 \\
\hline 4 & Benny Putari & Ind. & 2288 & 5.6 & 2388 & 4.2 & Excl 12 & 0 & 5.9 \\
\hline 11 & $\begin{array}{l}\text { Anubi Herowa } \\
\text { Ben }\end{array}$ & Ind. & 1086 & 2.7 & 1149 & 5.5 & Excl 11 & 0 & 2.8 \\
\hline 18 & Ronald Kulakua & Ind. & 983 & 2.4 & 1034 & 4.9 & Excl 10 & 0 & 2.5 \\
\hline 10 & David Kelo Kikabu & Ind. & 659 & 1.6 & 683 & 3.5 & Excl 9 & 0 & 1.7 \\
\hline 2 & $\begin{array}{l}\text { Walapi Kara } \\
\text { Geoffrey }\end{array}$ & Ind. & 574 & 1.4 & 575 & 0.2 & Excl 8 & 0 & 1.4 \\
\hline 5 & $\begin{array}{l}\text { Simon Haguale } \\
\text { Gawa }\end{array}$ & Ind. & 235 & 0.6 & 246 & 4.5 & Excl 7 & 0 & 0.6 \\
\hline 16 & $\begin{array}{l}\text { Johnson Balu } \\
\text { Wangale }\end{array}$ & Ind. & 88 & 0.2 & 89 & 1.1 & Excl 6 & 0 & 0.2 \\
\hline 19 & Lucy Pakalu & Ind. & 66 & 0.2 & 67 & 1.5 & Excl 5 & 0 & 0.2 \\
\hline 14 & $\begin{array}{l}\text { Ambu Michael } \\
\text { Sone }\end{array}$ & Ind. & 50 & 0.1 & 50 & 0.0 & Excl 4 & 0 & 0.1 \\
\hline 20 & Kenwa Ikila & Ind. & 42 & 0.1 & 42 & 0.0 & Excl 3 & 0 & 0.1 \\
\hline 17 & $\begin{array}{l}\text { Peter J. Harape } \\
\text { Nagiria }\end{array}$ & Ind. & 37 & 0.1 & 37 & 0.0 & Excl 2 & 0 & 0.1 \\
\hline 15 & $\begin{array}{l}\text { Anderson Andalu } \\
\text { Wabira }\end{array}$ & Ind. & 0 & 0.0 & 0 & 0.0 & Excl 1 & 0 & 0.0 \\
\hline
\end{tabular}

Total ballots remaining in count

Absolute majority

Exhausted ballot papers

Total allowable ballot papers

Informal votes
22,913

11,457

17,929 (43.9 of total allowable ballots)

40,842

187

(0.5 of total votes cast)

Total votes cast

41,029

$a$ Ind. = Independent; NA = National Alliance; PAP = People's Action Party; PNC = People's National Congress; URP = United Resources Party 
Election 2007: The Shift to Limited Preferential Voting in Papua New Guinea

Table 21.15: Voting statistics for Koroba-Lake Kopiago Open electorate, 2007 election

\begin{tabular}{lrr}
\hline Number of registered voters & 50,876 \\
Total votes cast & 45,020 \\
Informal votes & $547 \quad$ (1.2\% of total votes cast) \\
Total allowable ballot papers & 44,473 \\
Total ballot papers remaining in count & 30,066 \\
Total votes distributed & 28,656 \\
Exhausted ballot papers & $14,407 \quad$ (32.4\% of allowable ballots) \\
Absolute majority (50\% + 1) & 15,034 \\
\hline
\end{tabular}


21. Results at any Cost? The Legacy of 2002 in Koroba-Lake Kopiago Open Electorate

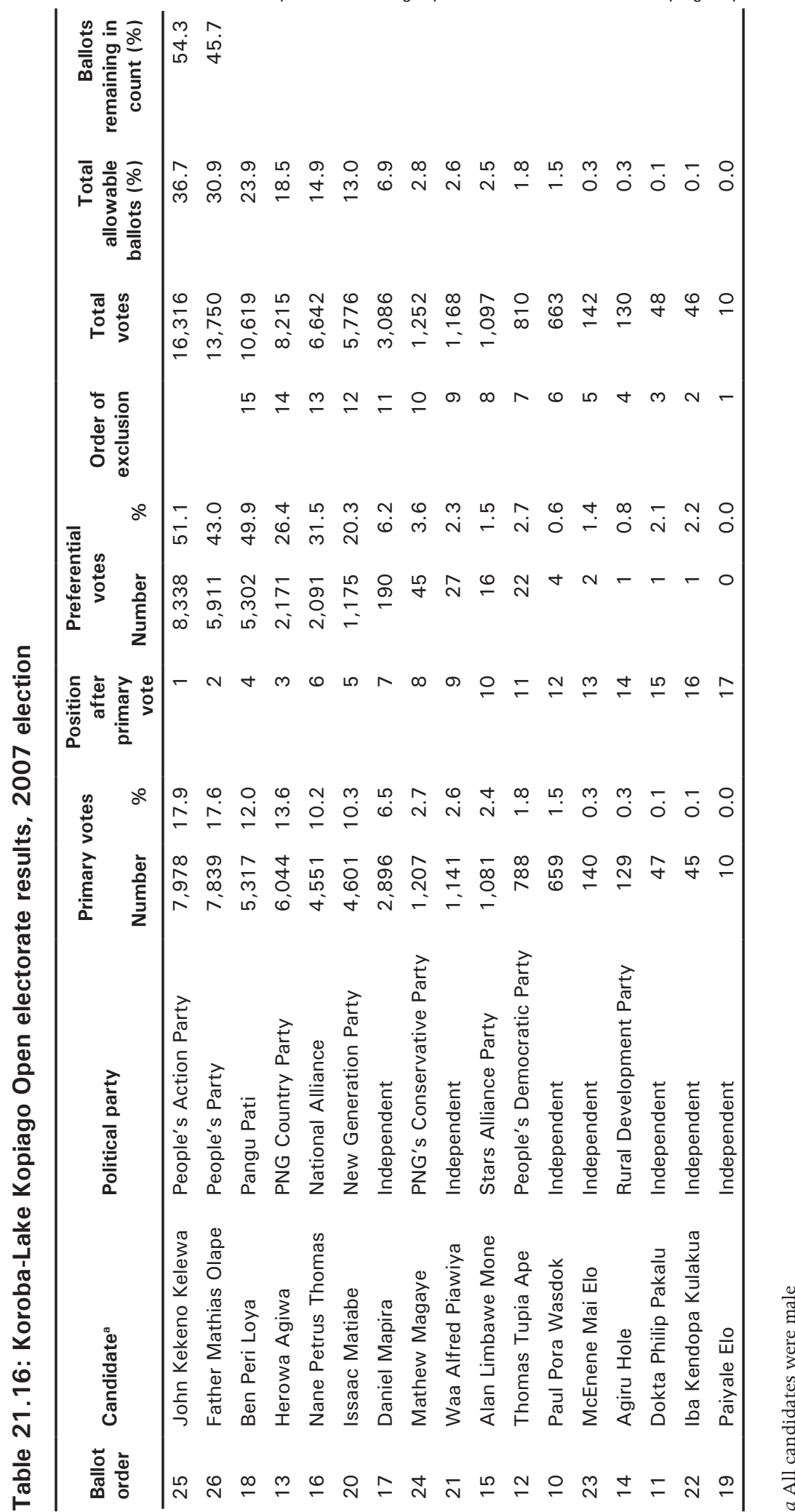

